UNIVERSIDADE DE BRASÍLIA

INSTITUTO DE CIÊNCIAS SOCIAIS

DEPARTAMENTO DE SOCIOLOGIA

\title{
JUSTIÇA RESTAURATIVA: \\ Análise das percepções dos Operadores do Direito do Superior Tribunal de Justiça
}

\author{
Autor: Ricardo Augusto Cavalari Pinheiro \\ Orientador: Arthur Trindade Maranhão Costa
}

Brasília-DF

2011 
UNIVERSIDADE DE BRASÍLIA

INSTITUTO DE CIÊNCIAS SOCIAIS

DEPARTAMENTO DE SOCIOLOGIA

\title{
JUSTIÇA RESTAURATIVA: \\ Análise das percepções dos Operadores do Direito do Superior Tribunal de Justiça
}

\author{
Monografia apresentada à Banca \\ examinadora da Universidade de \\ Brasília como requisito para a \\ obtenção do grau de bacharelado em \\ Ciências Sociais, com habilitação em \\ Sociologia.
}

Autor: Ricardo Augusto Cavalari Pinheiro Orientador: Arthur Trindade Maranhão Costa

\section{Brasília-DF}

2011 
Agradeço à Laiza Spagna, pelo exemplo de dedicação e comprometimento. Ao Jaime Cipriani, pelo apoio incondicional durante toda essa caminhada. Ao Professor Arthur Costa, pelo incentivo e suporte no desenvolvimento desse trabalho. 


\section{RESUMO}

Resumo: $O$ presente trabalho desenvolve uma análise, sob o ponto de vista sociológico, da Justiça Restaurativa e da percepção de Ministros e Assessores de Ministros do Superior Tribunal de Justiça a respeito dessa temática. Através de pesquisas bibliográficas e entrevistas semi-diretivas foi possível traçar um panorama das dificuldades enfrentadas pelo Sistema de Justiça formal, de caráter retributivo, e das possibilidades de aplicação das pratica restaurativas, inovadoras formas de administração de conflitos, na construção de soluções para o enfretamento dessas dificuldades. Assim, essa pesquisa objetiva compreender como os princípios e valores da Justiça Restaurativa são percebidos pelos operadores do direito, no âmbito do Superior Tribunal de Justiça, visando trazer à tona quais são os obstáculos para a disseminação de tais praticas e quais as suas reais aplicabilidades.

Palavras-chave: Poder Judiciário, administração de conflitos, Justiça Restaurativa.

\section{ABSTRACT}

Abstract: This work develops an analysis, from the sociological point of view, of restorative justice and the perception of Ministers and advisors of Superior Court of Justice about this subject. Through bibliographic researches and semi-directive interviews, was possible to trace the overview of the difficulties faced by the formal justice system, of retributive character, and the possibilities of application of restorative practices, innovative forms of conflicts administration, in construction of solutions to come up against these difficulties. Thereby, this research aims to understand how principles and values of restorative justice are noticed by legal operators, in the ambit of Superior Court of Justice, seeking to reveal what are the blockages to the spread of such practices and what are their real applicability.

Key-words: Judiciary Power, conflict administration, Restorative Justice. 


\section{SUMÁRIO}

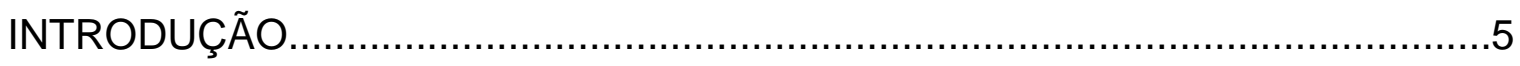

CAPÍTULO 1 - VIOLENCIA, CONFLITO E O PAPEL DO ESTADO.....................10

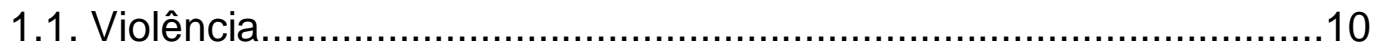

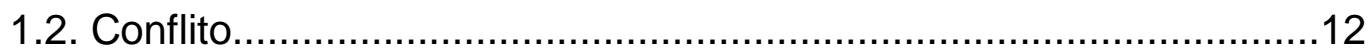

1.3. O Papel do Estado na Administração da Conflitualidade..................17

CAPÍTULO 2 - ACESSO À JUSTIÇA, JUSTIIÇA RESTAURATIVA.....................25

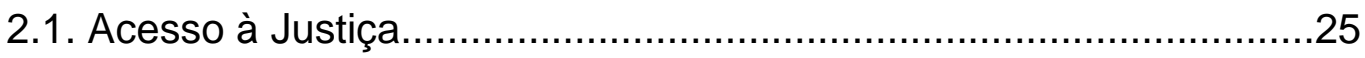

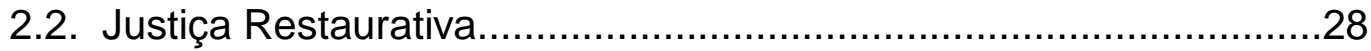

2.2.1. Panorama Histórico......................................................28

2.2.2. Princípios Restaurativos e Princípios Retributivos...........31

2.3. Justiça Restaurativa no Brasil.....................................................38

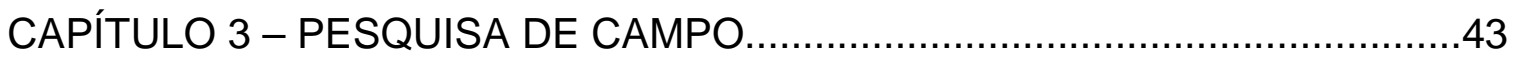

3.1. O Superior Tribunal de Justiça.....................................................43

3.2. Dificuldades enfrentadas pelo Poder Judiciário em relação

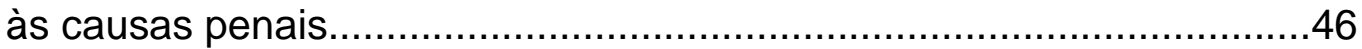

3.3. A Justiça Restaurativa na percepção dos entrevistados..................49

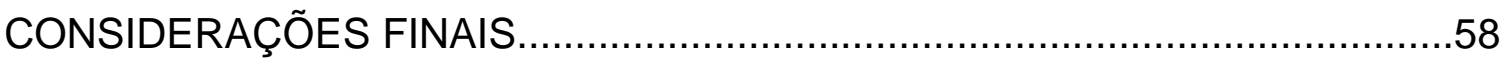

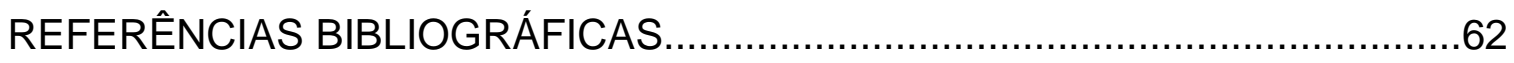

ANEXOS 


\section{INTRODUÇÃO}

As transições para a Democracia, em grande parte da América Latina, trouxeram a reboque crescentes níveis de violência (OXHORN, 2004). No Brasil não foi diferente e se percebe que o impacto da violência sobre os direitos civis básicos é uma das grandes ameaças à qualidade da democracia. (HOLSTON e CALDEIRA, 1998). Essa situação gera um estado permanente de insegurança na população que se agrava pelo baixo nível baixo de confiança nas instituições de justiça e na polícia, conforme explicita a pesquisa divulgada pelo Instituto de Pesquisas Econômicas Aplicadas em 2011, sobre a percepção social da Justiça no Brasil. Diante da pergunta: "De zero a dez, que nota você daria para a Justiça Brasileira?", a média nacional foi de 4,5. Na opinião de quem já acessou a Justiça, a média cai mais ainda, passando para 3,7.

Segundo Philip Oxhorn e Catherine Slakmon (2005), a combinação de baixos índices de confiança nas instituições estatais a altos índices criminais tende a criar um "círculo vicioso de violência". Estados fracos, onde é grande a falta de confiança nas instituições publicas, minam os direitos civis e fazem com que as instituições democráticas pareçam irrelevantes na resolução dos problemas básicos compartilhados pela sociedade. Estudos demonstram que a impunidade oriunda da ineficácia do Judiciário, aliada à deslegitimação da polícia em sua tarefa de manutenção da ordem são fatores que influenciam a recorrência da resolução violenta dos conflitos. (CALDEIRA, 2000; ADORNO, 2000). A morosidade do Judiciário, os altos índices de criminalidade, a ineficiência das instituições prisionais em relação ao seu suposto caráter ressocializante e as barreiras ao acesso à justiça, explicitam as dificuldades enfrentadas pelo Brasil no que diz respeito à Segurança Publica. Isso faz com que cresça a insatisfação, a insegurança da população e falta de confiança no Poder Judiciário. As classes menos favorecidas encontram, dentro desse contexto, diversas dificuldades para 0 acesso efetivo ao Sistema Judiciário, sendo elas sociais, culturais e econômicas.

Essas barreiras que inviabilizam o amplo acesso à justiça evidenciam um sistema democrático sem cidadania, onde a desigualdade socioeconômica afeta 
a essência do estado de Direito, na promoção do tratamento imparcial pela lei. Segundo Luiza Maria S. dos Santos Carvalho (2005:213):

"Tanto quanto as áreas econômica ou social, a capacidade legaljudicial em uma sociedade denota e é parte integrante da qualidade de seu desenvolvimento. A organização legal-judicial em uma sociedade é fundamental para garantir aos indivíduos a liberdade, o alcance dos direitos e as escolhas disponíveis."

A desigualdade acaba por interferir na imparcialidade da lei ao negar à grande parte da população o acesso efetivo à justiça. Visto que a desigualdade de tratamento e a exclusão de grande parte da sociedade, no que tange o acesso à justiça, são aspectos constitutivos do sistema de justiça criminal e de segurança publica brasileiros, segundo Roberto Kant de Lima (2005), faz-se cada vez mais urgente a implementação de novas maneiras de resolução de conflitos onde os socialmente vulneráveis não encontrem tantas barreiras, sejam elas de ordem material, formal ou simbólica, para o atendimento de seus pleitos.

Diante de tal realidade, a Justiça Restaurativa emerge como proposta para democratização do acesso à Justiça e, consequentemente, para amenizar deficiências do estado de Direito Punitivo. A Justiça Restaurativa se baseia em um procedimento voluntário, caracterizado pela informalidade, onde vitima, ofensor e, quando necessário, a comunidade atingida pela ofensa, participam ativamente na construção da solução do conflito. Há uma mudança de perspectiva em relação ao Sistema Retributivo, que atua com base em um paradigma de punição proporcional ao dano causado (HORWITZ 1990, apud JACCOUD, 2005), onde o Estado é o único responsável pela decisão de como o conflito deve ser resolvido, atribuindo culpa e estipulando a pena cabível. $O$ Sistema de Justiça Formal, busca a manutenção da ordem e a preservação da lei, por meio da punição, deixando a reparação dos danos causados em segundo plano. O enfoque da proposta retributiva está na violação à lei e não no dano causado por essa violação. Ao prever uma retribuição jurídica imaterial, o Estado pretende, através do exemplo da punição, evitar que os comportamentos desviantes se repitam e os indivíduos se afastem da ordem jurídico-penal, fixando normas coercitivas e sanções. Nesse cenário, vitima e ofensor tem pouco ou nenhum espaço para participarem ativamente da solução mais adequada às suas demandas. 
Nos procedimentos Restaurativos, por sua vez, os envolvidos tem um espaço para expressarem suas perspectivas a respeito do conflito. O diálogo é conduzido por um terceiro não envolvido no conflito, que tem a função de manter a comunicação equilibrada, gerando um ambiente de confiança entre as partes. (ZEHR, 2008). O protagonismo dado às partes durante o procedimento visa à definição consensual das melhores formas de solução do ocorrido, de maneira em que as necessidades dos envolvidos sejam supridas, tendo como enfoque a restauração das relações afetadas. Para Braithwaite (2002), esse espaço dado à exposição das motivações e dos sofrimentos dos envolvidos em relação ao conflito, tende a gerar a compreensão das perspectivas do outro e o perdão. Busca-se a reparação do dano causado e o restabelecimento das relações sociais atingidas pelo conflito.

Assim, a Justiça Restaurativa se apresenta como uma inovadora ferramenta para a eficaz resolução de conflitos podendo gerar uma vasta gama de benefícios para a sociedade. Em primeiro lugar, para o Sistema de Justiça Formal, a adoção de praticas restaurativas, mais informais e menos burocráticas, tende a causar a redução do volume de processos nos tribunais, permitindo que 0 Sistema Judiciário opere de forma mais eficaz e, consequentemente, melhore sua imagem e aumente o nível de confiança da sociedade na Justiça. Além disso, em um contexto em que a desigualdade socioeconômica penetra a esfera dos direitos necessários ao pleno exercício da cidadania, a democratização do acesso à justiça para segmentos marginalizados da sociedade é uma forma de empoderamento destes pela participação ativa no processo de justiça e pela disseminação do acesso à informação e aos recursos da justiça. Segundo Oxhorn e Slakmon (2005:203):

"Fundamentalmente, os programas de justiça restaurativa diferem de justiça tradicional no espaço que oferecem para a participação no processo de justiça. A participação dá poder. $O$ envolvimento ativo em projetos de micro-justiça, como administradores, usuários, ou como testemunhas participativas funcionam para dar poder aos cidadãos e comunidades desprivilegiadas."

Dentro desse escopo, o objetivo desse trabalho foi o de desenvolver uma investigação, sob o ponto de vista sociológico, do posicionamento de Ministros e 
Assessores do Superior Tribunal de Justiça, em relação a determinados pontos do Sistema de Justiça Retributiva e da Justiça Restaurativa, no tratamento de causas penais. Buscou-se observar qual a percepção desses operadores do direito no que diz respeito às possibilidades e impedimentos para a aplicação da Justiça Restaurativa no atendimento das demandas da sociedade por justiça, no que tange às questões criminais. Para tanto, foram efetuadas pesquisas documentais e bibliográficas a respeito dos princípios e fundamentos da Justiça Restaurativa, do Sistema de Justiça Retributivo e do Superior Tribunal de Justiça. Foram também utilizadas entrevistas semi-diretivas (COLOGNESE, 1998) e a analise dos discursos dos entrevistados.

O Superior Tribunal de Justiça foi escolhido como campo empírico da pesquisa devido à sua importância dentro do Sistema Judiciário brasileiro como Tribunal Superior que, além de desempenhar sua função constitucional relativa ao julgamento das causas de sua competência, exerce um papel de destaque na formulação de jurisprudências e na definição de posições que são seguidas pelas diversas instancias do judiciário e pelos operadores do direito em várias áreas. Como o objetivo desse trabalho é a análise as percepções dos Ministros e Assessores sobre a aplicabilidade das praticas restaurativas em relação às causas penais, a amostra pesquisada foi extraída da quinta e da sexta turmas em virtude da especialização das mesmas em matérias de Direito Penal. Assim, se buscou entrevistar o maior numero de ministros possíveis e, na impossibilidade de colher as opiniões de todos, devido à inacessibilidade de alguns, as entrevistas com seus assessores diretos foram de suma importância para desenharmos um panorama, que apresentou vários pontos convergentes, das representações dos operadores do direito do Superior Tribunal de Justiça referentes às dificuldades encontradas pelo Poder Judiciário para o atendimento das causas penas e à aplicabilidade das praticas restaurativas. Foram realizadas entrevistas com três Ministros e seis assessores diretos de Ministros. As entrevistas, que tiveram duração média de 25 minutos, foram realizadas nos Gabinetes dos Ministros ou de seus Assessores e gravadas com o consentimento dos entrevistados

O primeiro capítulo traz uma abordagem sociológica de questões relativas à violência e ao conflito, além de tratar do papel desempenhado pelo estado na tentativa de suprir as demandas relacionadas à conflitualidade. O segundo 
capítulo busca apresentar uma breve revisão bibliográfica sobre o acesso à Justiça no Brasil e sobre a Justiça Restaurativa. Traz um panorama histórico da temática e uma comparação, segundo os posicionamentos acadêmicos sobre o tema, dos conceitos, valores e princípios da Justiça Restaurativa e dos pontos divergentes em relação ao Sistema Retributivo. Também é feita uma análise das criticas enfrentadas pelos defensores deste modelo e da aplicabilidade do paradigma restaurativo no contexto sócio jurídico brasileiro. No terceiro e ultimo capítulo é desenvolvida uma análise das entrevistas realizadas com os Ministros e Assessores de Ministros do Superior Tribunal de Justiça visando compreender como estes percebem as dificuldades enfrentadas pelo Sistema Judiciário no atendimento das demandas relativas às causas penais e como enxergam a aplicabilidade das praticas restaurativas na tentativa de resolução desses conflitos. 


\section{CAPÍTULO 1 - VIOLENCIA, CONFLITO E O PAPEL DO ESTADO}

\subsection{Violência}

As ciências sociais propõem três principais abordagens clássicas sobre a temática da violência. A abordagem mais clássica insiste na idéia de que a violência é um comportamento de crise, é uma resposta à frustração. Essa proposta foi difundida por pesquisadores funcionalistas anglo-saxões, nas décadas de 60 e 70, sob a forma de uma teoria da frustração relativa que trazia a idéia de que a violência surge quando a distancia entre as expectativas de um grupo e a possibilidade de satisfação dessas expectativas se torna insuportável. Essa abordagem apresentou algumas limitações, apesar de produzir resultados interessantes, o que fez emergirem outras duas formas de abordagem amplamente aceitas (WIEVIORKA, 2007).

Outra abordagem é a desenvolvida na tese da "mobilização de recursos", que privilegia o caráter instrumental e racional da violência, na qual a violência é um recurso mobilizado por atores como um meio para alcançar seus objetivos. Essa idéia é de grande valia para a explicação de como os atores excluídos do campo político fazem uso da violência em busca de penetrarem e se manterem em tal campo. Apesar de ter como vantagem o fato de não mais apresentar a violência como uma conduta reativa que é apenas empregada em estados de crise, ela põe o ator em um lugar no qual ele está completamente consciente, defendendo uma explicação não negligenciavel da ação violenta, deixando à margem os fatores subjetivos do individuo (WIEVIORKA, 2007).

A ultima linha clássica de abordagem do tema, segundo Wieviorka (2007), se foca no vinculo entre cultura e violência. Por vezes a violência se contrapõe à cultura, como nos estudos de Norbert Elias nos quais o autor postula a relação entre o processo civilizador e o aprendizado do domínio da agressividade e de seus impulsos violentos pelos indivíduos ou, em outra ótica, onde se propõe uma vinculação entre cultura e violência que se transmite por processos de socialização que perpetuam idéias de intolerância.

Essas abordagens clássicas auxiliam no entendimento da violência, mas esquecem dimensões essenciais que devem ser trazidas à luz. Uma questão imprescindível é a noção de Sujeito. Segundo o autor: 
"Pode haver na violência aspectos que sugerem uma lógica de perda de sentido: o ator, então, vem exprimir um sentido perdido, pervertido ou impossível, ele é violento, por exemplo, porque não pode construir a ação conflitual que the permitiria fazer valer suas demandas sociais ou suas expectativas em matéria cultural ou política, porque não existe tratamento político para essas demandas ou expectativas." (WIEVIORKA 2007:1152)

Nota-se que muitos elementos relacionados à violência não são tratados com o devido cuidado pelas abordagens clássicas. É importante salientar que toda ação humana envolve alguns aspectos expressivos (subjetivos) e instrumentais (objetivos) e que a violência deve ser estudada como uma forma de interação (COSTA, 2011) que valorize tanto aspectos objetivos quanto subjetivos e só através de uma análise que englobe ambos os fatores e leve em consideração o contexto é que se pode ter uma visão mais abrangente a respeito da violência.

Tomaremos de empréstimo as reflexões Yves Michaud que, seguindo essa linha de abordagem mais holística, fornece uma contribuição de grande valia para o entendimento do tema. Para Michaud, (1989:11)

"Há violência quando, numa situação de interação, um ou vários atores agem de maneira direta ou indireta, maciça ou esparsa, causando danos a uma ou várias pessoas em graus variáveis, seja em sua integridade física, seja em sua integridade moral, em suas posses, ou em suas participações simbólicas e culturais".

O autor, em sua tentativa de definir "tanto os estados quanto os atos de violência" explicita a necessidade de que tal definição de conta das varias perspectivas envolvidas. Em primeiro lugar, é necessário se ater à complexidade das situações de interação, a violência não é vista apenas como o enfrentamento entre dois adversários, nela podem intervir múltiplos atores. Outro fato é a diversidade das modalidades de produção da violência de acordo com os instrumentos utilizados, na medida em que os adventos da tecnologia proporcionam uma violência cada vez mais "limpa". Também se deve levar em consideração a distribuição temporal da violência que pode ser:

“... ministrada de uma vez (maciça) ou gradualmente, até insensivelmente (distribuída). Pode-se matar, deixar morrer de fome ou favorecer condições de subnutrição. Pode-se fazer desaparecer um adversário ou afastá-lo progressivamente da vida social e política através de uma série de proibições profissionais e administrativas." (MICHAUD,1989:11). 
Por último, é importante salientar a diferenciação em relação aos tipos de danos que podem ser impostos pela violência, são eles: físicos, psíquicos e morais, aos bens, aos próximos ou aos laços culturais. Os danos materiais e físicos são considerados mais importantes, talvez por serem mais visíveis. Já os danos morais e psicológicos são considerados como mais irrelevantes e acabam tendo um tratamento mais condescendente por parte das autoridades judiciárias. Dessa forma, esse tipo de violência, que está intimamente relacionada aos conflitos interpessoais, acaba sendo tratada como irrelevante, quando comparado à violência causadora de danos físicos ou materiais. Isso se dá devido ao fato de que estas divergências interpessoais estão mais relacionadas às subjetividades dos indivíduos, o que torna a mensuração dos danos mais difícil de ser precisada. O que necessita ser ressaltado é que, às vezes, os danos materiais e/ou físicos são resultados de reiteradas violências relacionadas à esfera subjetiva.

\subsection{Conflito}

De forma geral, a violência subjetiva presente nos conflitos interpessoais tende a ser banalizada, em grande parte, pela sua ocorrência ser cotidiana e por sua pequena relevância jurídica. Isso faz com que os envolvidos em conflitos se sintam desamparados em relação às suas demandas por reconhecimento desse tipo de violência. Segundo (COSTA \& BANDEIRA, 2007) observa-se então o escamoteamento dos conflitos interpessoais e a intensificação das animosidades que acabam por gerar práticas violentas. Essa cultura de invizibilização dos conflitos interpessoais pode ser relacionada ao fato de essas violências serem voltadas, frequentemente, contra segmentos da sociedade que são historicamente fragilizados como mulheres, negros, indígenas, crianças, idosos, homossexuais, além de contra indivíduos pertencentes às classes econômicas menos favorecidas.

Seguindo essa linha conceitual, que revela a importância do dispêndio de atenção às questões relativas à violência subjetiva, se faz necessário um breve aprofundamento na teoria do conflito que servirá de marco teórico para esse trabalho. Nesse sentido, pode-se dizer que é consensual entre os fundadores da sociologia contemporânea, de Durkhein a Parsons, a primazia de Hobbes em sua abordagem sociológica sobre os fundamentos da ordem e sobre o surgimento do 
conflito, (Birbaum, 1995:250). Em sua análise, Hobbes descreve três causas que se destacam na formação dos conflitos: a competição em relação ao lucro, a desconfiança relacionada à necessidade de segurança e a necessidade de glória, relacionada à busca por reconhecimento e pela manutenção da reputação. Segundo o autor, o homem em seu estado de natureza tem a liberdade de usar seu poder, sua força da maneira que quiser, de acordo com seu próprio julgamento visando à satisfação de seus desejos e a preservação da sua própria natureza. Nesse conflito permanente de todos contra todos se estabelece, racionalmente, um preceito geral, um contrato que veta a prática de ações que privem a humanidade dos meios necessários à preservação da vida ou atentem contra ela. Essa regra geral torna necessária a criação de um estado detentor de poderes plenos e absolutos que ira gerir esse contrato de submissão que fundamenta a ordem social, promovendo a paz.

Marx inverte a dicotomia social presente na teoria Hobesiana e apresenta uma proposta na qual, na sociedade natural, os homens não tem, naturalmente, interesses contraditórios que os levam ao conflito e se encontram em uma comunidade solidária. É a emergência de uma sociedade baseada na propriedade privada que se apresenta como terreno fértil para os conflitos em razão da busca incessante pela acumulação de capital, de propriedade particular. Assim, a pacificação social se daria a partir de uma profunda mudança das relações econômicas que, gerando a abolição do estado, produziria o consenso. Nota-se que para Marx, o dito "normal", seria uma sociedade integrada e consensual onde o conflito é tido como uma exceção, uma "patologia", visão que, segundo Birnbaum (1995), representa, assim como a visão de Hobbes, uma teoria sociológica que reduz drasticamente o espaço de expressão do conflito.

O conflito, na ótica Durkheiniana, está ligado à sua concepção de integração social na qual toda sociedade "normal" desenvolve mecanismos de integração que limitam a amplitude dos conflitos (Birbaum, 1995). Em sua obra Da Divisão Social do Trabalho, Durkhein salienta que em sociedades baseadas na solidariedade mecânica, onde não há a divisão do trabalho, a integração social dependeria da força da consciência coletiva externa. Já em sociedades na qual a forma de integração se baseia na solidariedade orgânica, marcada pela divisão social do trabalho, a integração social está relacionada à interdependência dos atores. Durkhein propõe que a transição da integração social marcada pela 
solidariedade mecânica para a baseada na solidariedade orgânica implicaria na redução da amplitude dos conflitos visto que a interdependência das funções dos indivíduos fundamentaria a coesão social. O autor demonstra, dessa forma, uma perspectiva na qual "os conflitos surgem quase que como disfuncionais" (BIRNBAUM, 1995:251) e o "normal" seria a maior integração social, assim como para Marx. Enquanto que para Marx o conflito é provocado por uma disfunção na distribuição dos papéis sociais, oriunda da propriedade privada dos meios de produção, para Durkhein essa disfunção é causada pelo excesso de especialização ou pela transmissão hereditária de tais papeis. Essas interpretações não dão importância ao conflito em si e não ajudam a entendê-lo em sua essência. Segundo Birnbaum (1995:253):

"Daí que os dois fundadores da sociologia não nos permitam verdadeiramente construir uma teoria satisfatória do conflito: sua abordagem do fenômeno continua a ser demasiado reducionista e revela-se incapaz, devido a uma interpretação demasiado rígida das fontes dos conflitos, de apreender a sua extrema diversidade."

Na perspectiva Weberiana, busca-se o significado e os motivos que os próprios indivíduos atribuem as suas ações, o objetivo é compreender o sentido que cada pessoa dá a sua conduta e perceber, assim, a sua estrutura inteligível. $\mathrm{Na}$ proposta de Weber, deve-se compreender, interpretar e explicar respectivamente, o significado, a organização e o sentido, bem como evidenciar regularidades das condutas, ou seja, a sua idéia é a de que a sociedade como totalidade social é o resultado das formas de relação entre seus sujeitos constituintes. Tomando como ponto de partida para a compreensão da vida social o papel do sujeito, Weber tende a evitar o determinismo estrutural (BIRNBAUM, 1995:256). Nas palavras de Weber, a luta é "uma relação social na medida em que a atividade é orientada pela intenção de fazer triunfar sua própria vontade contra resistência do ou dos parceiros".

De acordo com essa análise, a luta entre os indivíduos em busca da imposição de suas vontades não cessará. O conflito passa a ser visto como "normal" nas sociedades, diferentemente das teorias de Hobbes, de Marx e de Durkhein, e não mais se relaciona a uma etapa de disfunção da sociedade, deixa de ser uma "patologia" e se torna inerente às configurações sociais (BIRNBAUM, 1995:256). Pode ser entendido como um processo social típico das sociedades, 
uma vez que estas são formadas por uma pluralidade de subjetividades, cujos interesses, por vezes divergentes, são colocados em contato.

É George Simmel que, ao desenvolver sua teria sociológica do conflito na qual este é apresentado como plenamente normal e vital para o funcionamento social, torna-se uma referencia para esse campo de estudo. Para Simmel (SIMMEL, 1908: 13-14):

"o conflito, uma das formas mais vivas de interações que não pode ser realizada por um único individuo, constitui um processo de associação. Os fatores de dissociação - o ódio, a inveja, a necessidade, o desejo - são as causas do conflito: o conflito eclode por causa deles. O conflito tem como missão, por conseguinte, resolver esses dualismos divergentes; constitui uma maneira de reconstruir certa unidade, ainda que através da destruição completa de uma das partes do conflito"

Simmel (1983) entende os conflitos como uma forma de interação e, apesar de poderem causar danos às relações particulares, desempenham um papel positivo na configuração social. Os conflitos também são uma forma de "sociação", surgem de elementos dissociativos presentes na sociedade e destinam-se a resolver "dualismos divergentes" sendo, então, uma condição da estruturação da sociedade e não uma anomalia. Originam-se da contraposição de interesses, de animosidades recíprocas ou de outras causas dissociativas que geram certa tensão entre os indivíduos e criam a possibilidade de uma reconfiguração da indisposição. O conflito é enxergado como uma fonte de regulação que estrutura grande parte dos campos sociais, é posto como uma possível maneira de resolução das divergências, seja através da negociação, da aniquilação da parte ou da desistência, com a capacidade de promover mudanças sociais.

Segundo Lewis Coser (1956) o conflito pode cumprir uma série de funções sociais. Nenhum grupo pode ser plenamente harmonioso, os grupos necessitam, para manterem suas dinâmicas, de associação e dissociação, o conflito pode, assim, contribuir para preservar a ordem social ao funcionar como válvula de escape. Pode ajudar a restabelecer a coesão que tenha sido ameaçada pelos antagonismos entre os membros do grupo. Outro ponto relevante é o fato de que os indivíduos, ao entrarem em conflito, aceitam normas comuns que regulam as partes, impondo determinadas restrições e estimulando a atualização dinâmica das regras, numa espécie de permanente revisão constitucional (COSER, 1956). 
Além disso, o conflito traz à consciência das partes e do grupo determinadas normas que poderiam não estar explicitas e, dessa forma, o conflito também apresenta uma faceta pedagógica e intensificadora da participação na vida em comunidade. $O$ conflito promove a aplicação de determinadas regras que poderiam estar esquecidas. Vale ressaltar que nem todos os conflitos são benéficos à estrutura do grupo, (Coser, 1956). Para o autor o conflito social será provisoriamente tomado como significando uma luta por valores e reclamação por "status", poder ou recursos escassos, em que os objetivos dos oponentes são neutralizar, ferir ou eliminar os seus rivais. As atitudes de hostilidade entre os membros do grupo são apenas uma predisposição para entrar em conflito enquanto o próprio conflito é sempre uma transação (COSER, 1956:7) O conflito consiste em um teste de poder entre partes antagônicas sendo que o poder é a capacidade de influenciar o comportamento do outro ou outros de acordo com seu próprio desejo.

Já Dahrendorf, autor que também segue os preceitos teóricos de Simmel, tem como um dos focos principais a regulação do conflito social. Para o autor, a distribuição desigual de autoridade constitui a principal fonte estrutural dos conflitos sociais e os conflitos contribuem para a integração dos "sistemas" sociais e os conduzem a determinadas mudanças. (DAHRENDORF, 1976: 207). O interesse pela regulação do conflito se aplica às expressões e não às causas devido ao fato das causas estarem relacionadas ao continuo antagonismo de interesses dos indivíduos e dos grupos. A eficaz regulação dos conflitos pressupõe a existência do reconhecimento por ambas as partes da necessidade e realidade da situação de conflito, a organização de grupos de interesses e o acordo, entre as partes, de algumas regras formais que permitam 0 enquadramento das suas relações. (DAHRENDORF, 1976:225).

Após esse breve panorama de algumas teorias sociológicas que tratam do conflito, seguiremos utilizando como marco teórico deste trabalho a teoria do conflito de Simmel, segundo a qual o conflito pode ser um fator de coesão social ao estabelecer fronteiras e fortalecer as identidades dos membros de um grupo, também pode estabelecer regras de disputa entre os grupos, pautas normativas que coordenam as relações. Uma classificação muito cara ao estudo que aqui pretendemos desenvolver diz respeito à especificação dos tipos de conflitos conforme o seu caráter, podendo ser mais objetivos e abertos, como nos conflitos 
por causas coletivas, em que os indivíduos atuam representando crenças, interesses, ou valores de um grupo ou podem ser mais intimista, como no caso dos conflitos interpessoais.

É importante salientar o protagonismo de Simmel (1983) em trazer à baila a necessidade de se dispensar atenção especial aos perigos da invizibilização dos conflitos interpessoais e da necessidade do reconhecimento das representações sociais dos indivíduos para a efetiva administração de seus conflitos. Determinadas práticas sociais, ao negarem ou escamotearem os conflitos interpessoais, não impedem a continuidade das hostilidades entre os sujeitos. Estas subjetividades negadas ou encobertas podem ser transferidas para outros objetos ou podem acabar se transformando em indisposições sociais, por vezes, mais intensas ou violentas. Para uma administração satisfatória, torna-se indispensável o entendimento do conflito em toda a sua complexidade material e simbólica e o reconhecimento das perspectivas das partes envolvidas, considerando os interesses que causaram a disputa e os danos gerados às partes e à sociedade, sejam eles materiais e/ou simbólicos.

Os conflitos interpessoais são conflitos de caráter habitual, que se desenvolvem no cotidiano das sociabilidades, provenientes de alguma interação anterior das partes. São, geralmente, discordâncias que se delongam no tempo, gerando um histórico para o conflito. Comungam de modos de expressão variados na esfera pública e/ou íntima das partes, podendo atingir terceiros não envolvidos na disputa. A notoriedade desta categoria de conflitualidade está ligada a dois aspectos fundamentais: são conflitos recorrentemente carentes de reconhecimento (Oliveira, 2002) na realidade jurídica e cultural do país, e, em contraste, têm desencadeado práticas graves de violência, muitas vezes também invisibilizadas. (SPAGNA, 2009).

\subsection{O Papel do Estado na Administração da Conflitualidade}

O Estado brasileiro tem se mostrado incapaz de administrar eficientemente conflitualidade presente na sociedade, principalmente no que se refere às questões relacionadas à violência subjetiva e aos conflitos interpessoais e nota-se um sentimento de insegurança e insatisfação por parte da população. Segundo Bauman (1998), as estratégias do estado mostraram-se tão inviáveis quanto o 
irreal funcionamento harmônico da sociedade. O contexto pós-moderno apresenta escassez de mecanismos que confiram a estabilidade necessária à realidade social para que indivíduos erijam identidades subjetivas de forma fidedigna e duradoura. Ao contrário, o que se percebe é uma disseminação de conflitualidades e incertezas a respeito da configuração do mundo e no futuro das relações sociais. A imposição de uma ordem social é muito mais um processo descontínuo que a petrificação de uma lei eterna. Contudo, a inconstância que a pós-modernidade trouxe ao conteúdo e à forma dessa ordem refletiu, diretamente, na construção de subjetividades, impedindo delimitações tenazes como no passado e trazendo angústia e mal-estar característicos a seus autores, uma vez que essa nova forma de incerteza não é superada com esforço individual e não tem delimitação temporal. Nas palavras do próprio autor ela é "permanente e irredutível" (BAUMAN, 1998).

Bauman (1998) sugere fatores que considera responsáveis, em grande medida, por essa versão da realidade pós-moderna. Na esfera política, pondera a respeito de uma desordem global em função de estratégias, negociações, associativismos e conflitos que surgiram ao longo da história e impossibilitaram o vislumbre claro da lógica de arranjo dos blocos de poder. No âmbito econômico impera a desregulamentação, em função da liberalidade da economia de mercado reinante, emergindo daí graves problemas sociais. $O$ terceiro ponto seria 0 esfacelamento das outras instâncias basilares da rede que une os indivíduos e colaboram na sedimentação do sentimento de segurança pessoal: famílias, associações, vizinhança, clubes. Nesse cenário é notável a mudança nas relações interpessoais, comparativamente com a sociedade moderna, em muito devido ao desenvolvimento de uma sociedade consumista e utilitarista que se dissemina rapidamente.

Grande parte dos laços interpessoais perde seu traço de caráter duradouro, passando a se estruturar de acordo com o benefício que uma pessoa pode trazer para outra. Se, por um lado indivíduos transitam com maior facilidade entre as instâncias sociais, que ganham plasticidade, por outro, tais instâncias tornam-se menos duradouras. Nessa esfera, a recorrência dos conflitos interpessoais evidencia a necessidade de seu reconhecimento e da administração adequada (BAUMAN, 1998). 
Na visão de Loic Wacquant (2001), em sua obra "As prisões da miséria" são grandes os prejuízos causados pela a adoção de políticas neoliberais por países de economias capitalistas após a Revolução Industrial, no que tange a administração de conflitos. Esses países desprezaram o Estado de Bem estar social e, ao adotarem as práticas da economia de mercado, auto-regulável e de intervenção acabaram por dispensar aos problemas sociais uma política de repressão policial e penalização Judiciária. Há uma falta de enfoque nas questões sociais em contraponto à mercantilização imposta pelo neoliberalismo e a concomitante emergência do Estado penal.

Muitos foram os efeitos sociais das transformações do mundo do trabalho, que vieram a reboque da industrialização e desenvolvimento tecnológico capitalista, a partir do século XX. É claro que as condições sociais antes de tal data não eram exemplares, contudo, a partir da década de 1970, as exigências atuais de mercado, a competição acirrada, e a necessidade de crescimento constante na produtividade recaíram sobre a condição do trabalhador, precarizando-a: trazendo a incerteza constante quanto a seu futuro, ligando a existência social à ocupação de uma atividade produtiva, e fazendo-os abrirem mão de direitos e garantias conseguidos com lutas passadas. Tem-se daí, um grande contingente de supranumerários, a margem da cena social central, vivendo sob condições de pobreza e desigualdades cotidianas, relevados ao esquecimento social em guetos e periferias isoladas, e adotando o que Weber coloca como "capitalismo de pilhagem", ou seja, valendo-se dos próprios meios para sobreviver. Não é difícil de entender, portanto, os atuais problemas sociais que atingem as sociedades pós-modernas (em especial, as de tradição democrática incipiente e industrialização recente): altos índices de criminalidade e violência, insegurança social, marginalização e estigmatização - e até eliminação - de grupos de indivíduos que vivem à margem da sociedade. (WACQUANT ,2001)

Contudo, a forma encontrada pelos Estados Unidos da América para tratar dessas questões socioeconômicas, ao contrário de buscar solucionar suas causas, foi eliminá-las pela repressão, ou seja, adotando práticas de segurança social de rigor inflexível e caráter extremamente ofensivo, para retirar das ruas e da evidência social esses indivíduos que abaixam os índices de desenvolvimento humano e denunciam a densa problemática social estadunidense. Com a 
chamada Política de Segurança Zero, Rudolph Giuliani, prefeito da cidade de Nova York, e Willian Bratton, chefe da polícia municipal, conseguiram reduzir os índices de criminalidade num pequeno espaço de tempo. Seguindo essa via, tal política conquistou adeptos em vários outros países, galgando a legitimação da gestão policial e judiciária da pobreza em várias partes do mundo. (WACQUANT, 2001)

A construção desse discurso de criminalização da miséria como saída à insegurança social se tornou bastante aceito. Nesse sentido, a produção midiática e acadêmica surge rapidamente com intuito de fundamentar tal discurso utilizando-se de argumentos de especialistas, cientistas, consultores, acadêmicos, cujas palavras têm grande aceitação pelo senso comum, além da campanha propagandística que também surte grande efeito na sociedade. Segundo Wacquant (2001: 7):

\begin{abstract}
"a penalidade neoliberal ainda é mais sedutora e mais funesta quando aplicada em países ao mesmo tempo atingidos por fortes desigualdades de condições e de oportunidades de vida e desprovidos de tradição democrática e de instituições capazes de amortecer os choques causados pela mutação do trabalho e do indivíduo no limiar do novo século".
\end{abstract}

Wacquant lança luz sobre uma séria falha endêmica desse mecanismo de repressão, a sobrecarga dos tribunais, uma vez que para cada atuação instaurase um inquérito e um processo judicial gerador de gastos empreendidos em equipamento e pessoal, bem como em suporte a ser dado ao novo contingente de detentos, construção de presídio, etc.

Percebendo essa incapacidade do estado em garantir o estado de bem estar social e a sua inabilidade na administração de conflitos, Guillermo O'Donnel (1998) se foca nas questões relativas à democracia, cidadania e fatores que fazem parte da sistematização de um estado de direito pleno, fatores esses que não se desenvolveram efetivamente nos países da América Latina. Nesse sentido, o autor traz para o debate a utilização do conceito de democracia para caracterizar as novas gestões governamentais presentes em países da América Latina. Recém saídos de regimes autoritários, esses países apesar garantirem os direitos políticos aos cidadãos, não são capazes de garantirem direitos civis e sociais. Se por um lado garantem eleições regulares, sistema eleitoral eficiente e 
confiável e liberdades políticas asseguradas, por outro apresentam profundas desigualdades e deficiências socioeconômicas.

Na década de 70 a América Latina viveu uma onda de regimes autoritários através da instalação de várias ditaduras militares de estruturas semelhantes. Em 80 os países, em grande parte, passaram por processos de redemocratização que colocaram fim aos regimes militares e devolveram aos cidadãos uma série de direitos e garantias, que haviam sido extirpados. É a partir dos anos 90, que se verifica um aumento no grau de liberdades individuais e direitos políticos, esse novo período também evidencia algumas dificuldades para o estabelecimento pleno das democracias o que leva alguns autores a proporem que, em função das heterogeneidades econômicas e sociais que permaneceram nos países da América Latina, a transição política foi de um regime para outro que não a democracia (O'DONNEL 1998). Segundo o autor, o Estado de Direito é pensado como sendo o fator de garantia da limitação à ação do Estado e da aplicação isonômica da lei. É por ele que se verifica a regulação da agência do Estado, demarcando a competência de poder de seus membros, representantes e instituições; bem como a proteção da justiça dos atos normativos, devendo ser aplicados de forma igual a todos os indivíduos. Os agentes institucionais devem se regular pelas leis e garantir que as mesmas sejam aplicadas de forma igualitária.

O Brasil também apresenta essa dicotomia tão evidente na América Latina, apesar da existência um regime democrático consolidado em seu aspecto político, o exercício do poder é, frequentemente, não democrático. Certa forma de validação dessa dicotomia é a conformidade da população, que aceita as violações do Estado de Direito por parte das autoridades, fazendo com essas violações se legitimem como práticas autônomas, esperadas e justificáveis. Nesse sentido, verifica-se a criação de um Estado pela lei em oposição ao Estado das leis, no sentido de que as ofensas ao Estado de Direito se fazem valer por mecanismos legais: burocracias, decretos, e outras medidas judicialmente aceitas, ainda que inconstitucionais, que passam sem grandes contestações pela sociedade civil. Dessa forma, a democracia brasileira deturpa o caráter liberal do modelo democrático teórico, não delimitando claramente as ações do Estado, bem como a idéia republicana, com a aplicação abusiva e desigual da lei em função das características pessoais dos atores sociais. Formalmente, nossa 
legislação é exemplar quanto à constituição de um Estado de Direito, contudo, sua aplicação é que se faz problemática: não são as normas, mas as práticas sociais, bem como os valores nelas incutidos, que permeiam as instituições estatais com desigualdades e criam barreiras (sociais, econômicas, físicas e simbólicas) para o pleno exercício da cidadania.

Tendo em vista essa ineficiência do Estado em fornecer à sociedade segurança e a garantia dos direitos previstos na constituição influenciada, em larga medida, pela desigualdade na distribuição de renda que promove a exclusão social de grande parte da população e a consequente perda de direitos fundamentais como emprego, moradia, educação e saúde. Um dos direitos que acaba não sendo respeitado pelo estado diz respeito ao acesso à justiça. Em uma sociedade onde a igualdade de possibilidades é apenas formal e não efetiva, é preciso levar em consideração alguns obstáculos, alguns fatores impeditivos ao exercício pleno dos direitos. Vale ressaltar que o acesso à justiça, visando à manutenção ou reparação de direito, é resguardado pela Constituição em seu artigo 5o, que busca preservar a máxima na qual: todos são iguais perante a lei sendo invioláveis a vida, a liberdade, a igualdade, a segurança e a propriedade.

Alguns fatores considerados de grande relevância para a explicação da ineficácia do estado na garantia dos direitos democráticos aos cidadãos dizem respeito aos entraves impostos à promoção de mudanças estruturais profundas devido à concepção punitiva adotada no Brasil. Sabe-se que o retorno ao regime democrático após o período de ditadura militar, trouxe a esperança de que os direitos humanos seriam mais respeitados. Segundo Pinheiro (1997):

\footnotetext{
"que os direitos humanos alcançados para a proteção das oposições políticas sob as ditaduras militares pudessem vir a ser estendidos para todos os cidadãos, em especial para aqueles grupos mais destituídos e vulneráveis"
}

Porém, apesar de terem sido eliminadas as formas mais brutais de dominação, usadas contra os dissidentes políticos, o Brasil ainda não conseguiu garantir efetivamente os direitos de cidadania presentes em sua legislação. O que se percebe é que a abertura política e a consequente ampliação dos direitos não foram capazes de solidificar os valores democráticos primordiais, como as garantias constitucionais individuais ou a proteção aos direitos humanos. Se durante a transição democrática se esperava que o fim da ditadura significasse a 
consolidação de tais direitos o que se vê realmente é que as práticas autoritárias não foram efetivamente alteradas pelas mudanças políticas e as instituições estão cada vez mais submetidas a interesses privados. Segundo Milton Lahuerta (2003:217), "se há um traço que marca a experiência brasileira no século XX é a presença simultânea de um intenso processo de modernização e de um baixíssimo compromisso com as instituições democráticas".

Nota-se que o projeto liberal se adaptou com bastante sucesso à realidade brasileira do final dos anos 80 , Esse projeto neoliberal se caracteriza pela mínima intervenção econômica e social por um lado e a responsabilidade pelo controle dos transtornos sociais advindos desse modelo, por outro. Em virtude dessa postura altamente controladora em relação aos conflitos sociais o aumento da insegurança da população acaba por legitimar o aumento da repressão por parte do estado. O viés liberal de um "Estado Mínimo" promove, no campo jurídico, a equação penal que apresenta a pena severa como a única medida capaz de controlar e diminuir a criminalidade. (PESTANA, 2009), No modelo atual, o que caracteriza a atuação penal é a exclusão e o isolamento visto que o estado não promove o objetivo educador e reformador que deveria estar presente no sistema prisional. Esse abandono do discurso ressocializador permite que cada vez mais a punição seja considerada como um "instrumento de encarceramento de uma população considerada tanto desviante e perigosa como supérflua, no plano econômico" (WACQUANT, 2001: 98).

Grande parte da população fica então submetida a um imenso sistema penal responsável por conter o refugo social ao invés de disciplinar os desviantes e restaurar a ordem. Wacquant considera, ironicamente, tal fenômeno como "uma espécie de único programa público habitacional do capitalismo tardio" (WACQUANT apud BATISTA, 2003). No Brasil, então, as respostas à criminalidade consistem, em grande parte, em penas severas que desrespeitam as garantias constitucionais ao adotarem uma política de posição punitiva voltada para a defesa da lei e da ordem, mas materializada em um tratamento penal excessivo e desigual. Nesse contexto o Poder Judiciário cumpre uma função de proteger a elite, agindo com rigor no combate à criminalidade que provem das classes mais desfavorecidas. $O$ campo jurídico associa a eficiência à repressão, a legitimidade está na atuação autoritária. (PESTANA, 2009) 
Essa concepção hegemônica da Justiça Penal vê na punição o único caminho para o controle das desordens causadas pelo aumento das mazelas sociais, sendo que os operadores do direito agem como "novos faxineiros da modernidade" (PESTANA, 2009). Nesse contexto, se consolida uma sociedade de exclusão onde o que se vê é uma democracia sem cidadania onde a desigualdade socioeconômica afeta diretamente a integridade do estado de Direito na sua essência de promover à população um tratamento imparcial pela lei. A desigualdade acaba por interferir na imparcialidade da lei ao negar à grande parte da população o acesso efetivo à justiça. Segundo T. Marshall (1967) sendo o elemento jurídico das garantias civis de grande relevância ao assegurar a igualdade de condições e o devido encaminhamento legal aos demais direitos, o atual contexto do cenário jurídico fere o pleno exercício da cidadania. Torna-se necessário a criação e disseminação de novos meios, mais abrangentes e democráticos, de acesso à justiça, novos mecanismos mais eficientes de administração de conflitos em busca do exercício pleno da cidadania.

Visto que a desigualdade de tratamento e a exclusão de grande parte da sociedade, no que tange o acesso à justiça, são aspectos constitutivos do sistema de justiça criminal e de segurança publica brasileiros, segundo Roberto Kant de Lima (2005). Faz-se cada vez mais urgente a implementação de novas maneiras de resolução de conflitos onde os socialmente vulneráveis não encontrem tantas barreiras, sejam elas de ordem material, formal ou simbólica, para 0 atendimento de seus pleitos. É dentro desse escopo que se pretende analisar as praticas da Justiça Restaurativa como uma maneira de flexibilizar o sistema de justiça criminal, disseminando o acesso à justiça ao fornecer respostas mais adequadas à variedade de demandas existentes nessa complexa teia social contemporânea. 


\section{CAPITULO 2 - ACESSO À JUSTIÇA E A JUSTIÇA RESTAURATIVA}

\subsection{Acesso à Justiça}

Ao se falar sobre o tema do acesso à justiça torna-se interessante que seja traçado um breve histórico das transformações sofridas pelo conceito de acesso à justiça. Durante os séculos dezoito e dezenove o direito ao acesso à proteção jurídica podia ser resumido, basicamente, ao direito formal da parte propor uma ação. O estado permanecia passivo e não se importava com a incapacidade das pessoas de utilizar efetivamente a justiça. À medida que o conceito de direitos humanos começou a sofrer alterações e o estado passou a ter um papel mais ativo na busca da garantia dos direitos sociais do indivíduo, o direito ao acesso à justiça passa também por grandes transformações e começa a ser reconhecido como de suma importância para o pleno exercício da cidadania.

Buscando a viabilização do acesso efetivo à justiça, Cappelletti afirma (CAPPELLETTI, GARTH, 1988: 15):

"[...] A efetividade perfeita, no contexto de um dado direito substantivo, poderia ser expressa como a completa "igualdade de armas" - a garantia de que a conclusão final depende apenas dos méritos jurídicos relativos das partes antagônicas, sem relação com diferenças que sejam estranhas ao Direito e que, no entanto, afetam a afirmação e reivindicação dos direitos. Essa perfeita igualdade, naturalmente, é utópica. As diferenças entre as partes não podem jamais ser completamente erradicadas. A questão é saber até onde avançar na direção do objetivo utópico e a que custo. Em outras palavras, quantos dos obstáculos ao acesso efetivo à justiça podem ser atacados?"

A partir da década de 1960 várias iniciativas tem sido implantadas, de acordo com Cappelletti e Garth (1988) esse movimento de aprimoramento pode ser dividido em três momentos, ou "ondas" que buscam resolver diferentes carências em relação à problemática do acesso à justiça.

A primeira "onda", iniciada em 1965, tem o intuito de prestar assistência jurídica aos pobres. O elevado valor das custas processuais, a falta de recursos para o pagamento de um advogado, a falta de conhecimento jurídico são alguns dos fatores que impedem o acesso de grande parte da população A maquina do judiciário. Visando solucionar esses problemas que afastam a população mais carente do judiciário os governos de vários países têm proporcionado 
representação e assistência jurídica gratuitas aos menos favorecidos através de diferentes sistemas nos quais os advogados são pagos pelo estado.

A segunda "onda" tem como principal questão a representação dos interesses difusos e interesses relacionados a grupos. Devido ao caráter altamente individualista do processo carecia-se de instrumentos jurídicos que abarcassem as demandas de uma gama maior de sujeitos em uma mesma ação. Foram criados, então, mecanismos de viabilização de defesa dos direitos difusos (coletivos) visando o atendimento dos pleitos dos grupos, classes ou categorias de pessoas reunidas pela mesma situação de fato, que de outra forma não teriam força na defesa de tais interesses.

A terceira "onda" diz respeito a uma reforma interna do processo objetivando conceder representação aos direitos individuais, difusos, públicos e privados preenchendo os "vazios de tutela". O aprimoramento dos mecanismos processuais simplificando procedimentos e criando formas alternativas de acesso à justiça é característica dessa onda, na qual o conceito de efetividade entra em cena visando melhoras qualitativas na prestação jurisdicional.

Conforme Cappelletti (CAPPELLETTI, GARTH, 1988: 71):

"[...] encoraja a exploração de uma ampla variedade de reformas, incluindo alterações nas formas de procedimento, mudanças na estrutura dos tribunais ou a criação de novos tribunais, o uso de pessoas leigas ou para profissionais, tanto como juízes quanto como defensores, modificações no direito substantivo destinadas a evitar litígios ou facilitar sua solução e a utilização de mecanismos privados ou informais de solução dos litígios. Esse enfoque, em suma, não receia inovações radicais e compreensivas, que vão muito além da esfera de representação judicial".

Seguindo esse movimento em busca da democratização do acesso à justiça começam a ser criados, em 1995, no Brasil, os primeiros Juizados Especiais. Voltados para a resolução de causas consideradas de menor complexidade são divididos em cíveis e criminais e se orientam pelos critérios de economia processual, simplicidade, informalidade e rapidez, visando sempre a conciliação das partes envolvidas nos conflitos. Em 1996, tem inicio, através da criação da lei de arbitragem, uma nova perspectiva sobre as maneiras de resolução de conflitos sem que haja a obrigatoriedade da intervenção de um juiz. $\mathrm{Na}$ arbitragem, além de definirem os procedimentos que orientaram o processo, 
as partes solicitam a intermediação de um profissional técnico para o esclarecimento do problema, prevalecendo a autonomia das partes envolvidas.

Outro importante instituto é o da conciliação, no qual se prioriza a comunicação livre entre os interesses conflitantes. As partes confiam a um conciliador, uma terceira pessoa neutra, a função de orientá-las na construção de um consenso, criando um ambiente propício para a harmonização dos interesses de forma mais barata, mais rápida e mais pacificadora do que no processo formal. O conciliador investido de autoridade para sugerir propostas busca, então, a formulação de um possível acordo entre os envolvidos. A mediação vem complementar as outras formas citadas de resolução de conflitos. Nessa modalidade, um terceiro, estranho e neutro, atua como facilitador sem interferir na decisão final das partes, sua função é tentar encontrar um ponto de equilíbrio na controvérsia, objetivando uma solução que seja a mais justa possível. As partes, sob a supervisão de um mediador, buscam a aproximação dos interesses em comum no intuito da viabilização consensual de um acordo

Na mão desse movimento de democratização e humanização da justiça, cresce o numero de iniciativas relacionadas às formas alternativas de resolução de controvérsias. Tais sistemas alternativos não visam substituir as maneiras formais de acesso ao Judiciário e sim, ser um mecanismo complementar na gestão dos antagonismos de interesses presentes nas sociedades. 0 ordenamento jurídico brasileiro tende a buscar na litigiosidade, onde as questões são resolvidas de forma impositiva pelo Estado, o principal meio de resolução, afastando das mãos dos indivíduos tal poder. Na história, várias culturas utilizaram e utilizam formas alternativas que, na maioria dos casos, são praticadas complementarmente ao poder jurisdicional formal do estado e não como uma forma substitutiva. As sociedades tiveram e tem, ainda hoje, dois caminhos a seguir na administração de conflitos: através da negociação direta, com ou sem a mediação de um terceiro, ou pelo confronto, exigindo a imposição de uma decisão por parte do ente estatal.

No Brasil, o estado se apresenta como última instancia de poder com capacidade para proteger a sociedade, um estado dotado de legitimidade para punir os comportamentos que se desviem dos padrões legitimados (Boudon, 1995). Esse Estado, comprometido com a ordem social, armou-se de institutos para coagir e repudiar ameaças à coesão e ao funcionamento harmônico do todo, 
na tentativa de assegurar a tão desejada estabilidade no seio da sociedade (Bauman, 1998). É diante de tal realidade que a sociedade vem buscando o desenvolvimento e a implantação de novas formas de resolução de conflitos que consigam dar respostas rápidas e eficazes à população que, diante da complexidade do mundo moderno, desenvolve demandas cada vez maiores por igualdade e cidadania, conforme salienta a Ministra do Superior Tribunal de Justiça, Nancy Andrighi (1993:9)

"Como se vê, os ventos da modernidade indicam, nas atuais circunstâncias, a necessidade imperiosa de mudar a tradicional forma de trabalhar, tanto dos juízes quanto dos advogados, no sentido de evitar o máximo possível a beligerância, investindo no esgotamento das tentativas de solução extrajudiciais, abandonando as atitudes formalista de "manter por manter" o antagonismo estéril e a postura de confrontação inútil dos contendores. A adoção de formas alternativas de solução de conflitos propugna seu entrelaçamento profícuo com os membros do Poder Judiciário, porque a colaboração mútua é a única forma de fazer vingar tais vias alvissareiras no País."

A Justiça Restaurativa se insere nesse panorama buscando a modernização e humanização da justiça através de ideais de restauração das relações sociais ao invés da penalização do réu, traço característico do sistema formal. Dessa forma, segundo Scuro Neto (2000), busca se reparar as consequências, reconstruir as relações entre os afetados, enfatizando a cura das feridas sofridas pela sensibilidade, pela dignidade ou reputação, destacando a dor, a mágoa, o dano, a ofensa e o agravo causados pelos envolvidos.

\subsection{Justiça Restaurativa}

\subsection{1 - Panorama Histórico}

O paradigma da Justiça Restaurativa remonta, de certa forma, às sociedades comunais que, em decorrência do modelo de organização social que adotavam, privilegiavam as praticas de regulação social baseadas na manutenção da coesão grupal (JACCOUD, 2005). Embora existissem formas punitivas de resolução de problemas relacionadas às transgressões das normas, as sociedades comunais, onde os interesses coletivos se sobrepujavam aos interesses particulares, tendiam a buscar uma solução que restabelecesse o equilíbrio rompido visando à contenção da desestabilização do grupo. 
Alguns princípios das praticas restaurativas podem ser encontrados em códigos decretados desde 2050 a.C., como no caso do código sumeriano que previa restituição no caso de crimes violentos. Também se encontram tais princípios entre os povos colonizados na África, Austrália, Nova Zelândia, América do Sul e do Norte e entre sociedades Europeias pré-estatais. (JACCOUD, 2005). A centralização dos poderes e o surgimento dos estados nações modernos reduzem consideravelmente estas formas de solução de conflitos negociadas, afastando a vitima do processo criminal e quase extinguindo as formas de reintegração social nas práticas jurídicas, através da imposição de um sistema de direito único pelos colonizadores (DUPONT-BOUCHAT, 1999).

O conceito de Justiça Restaurativa surgiu em 1975, criado pelo psicólogo americano Albert Eglash que buscava a reformulação do modelo terapêutico, no qual defendia uma nova forma de resolução de conflitos onde o ofensor é auxiliado a encontrar formas de pedir perdão às vitimas por ele ofendidas e ter uma nova oportunidade auxiliando outros ofensores (EGLASH, 1958). O pesquisador estabeleceu a divisão das formas de controle social dos comportamentos desviantes criminalmente em: modo retributivo, que se pauta na punição proporcional ao crime cometido; modo distributivo, que se pauta na reeducação e no tratamento do infrator; e modo restaurativo, que se fundamenta na reparação dos danos causados às partes. A perspectiva de Eglash difere dos modelos atuais de Justiça Restaurativa, pois propõe uma espécie de forma supervisionada do ofensor pedir perdão à vitima e, alem disso, dá pouca atenção à vitima durante o procedimento (PINTO, 2007).

É importante salientar que os vestígios da Justiça Restaurativa são encontrados em sociedades comunais e pré estatais em geral e não só em práticas dos povos nativos, o que leva a crer que tais praticas estavam mais ligadas à estrutura social do que à cultura das sociedades. Segundo Faget (1997), três correntes de pensamento influenciaram o ressurgimento da Justiça Restaurativa nas sociedades contemporâneas do ocidente, são elas: $O$ movimento da descoberta da vitima, o movimento de contestação das instituições repressivas e o de exaltação da comunidade. O movimento de descoberta da vitima surge após a segunda guerra mundial impulsionado por um discurso de cunho cientifico sobre as vitimas, chamado de vitimologia. Tal movimento que busca o entendimento das razões da vitimização vai ser responsável pela 
sensibilização para as necessidades da vitima e para a sua ausência no processo penal. Já os movimentos de contestação das instituições repressivas, marcado pelos trabalhos da Escola de Chicago e de Berkeley, nos Estados Unidos, buscam o desenvolvimento de uma justiça mais humanista e não punitiva. $O$ movimento de exaltação da comunidade ou promoção das virtudes comunitárias advoga a valorização da negociação comunitária nos conflitos (FAGET, 1997). Esses três movimentos foram de grande influencia para concepção contemporânea de Justiça Restaurativa.

Vários outros fatores impulsionaram o desenvolvimento de formas alternativas de resolução de conflitos, dentre eles: a descentralização do poder do estado, a complexificação das relações sociais, o aparecimento e fortalecimento da sociedade civil, a fragmentação dos centros de decisão e a elevação do neoliberalismo, configurações que fomentaram a remodulação estrutural das relações entre estado e cidadão. (De Munck, 1997; Cartuyvels, Digneffe e Kaminski, 1997; Génard, 2000, apud JACCOUD, 2005). Tais relações passam a se fundamentar em uma maior participação da população na administração de vários setores da sociedade, isso reflete no campo penal que passa a reforçar a ação penal em delitos graves e tende a delegar à instancias sócio-comunitárias as ofensas secundárias (JACCOUD, 2005). Percebe-se, então, que a Justiça Restaurativa surge como fruto de uma complexa conjuntura, composta por vários movimentos de cunho cientifico e de tendências políticoadministrativas que impulsionam a criação ou o ressurgimento remodelado dessa forma de resolução de conflitos.

As praticas restaurativas surgem como uma interessante maneira de se buscar a transformação das praticas desenvolvidas no sistema penal vigente. Uma forma diferente do sistema tradicional de Justiça criminal que aborde os conflitos como uma violação nas relações entre os envolvidos que devem ser restauradas (PINTO, 2005). Em 2002 as praticas restaurativas se consolidam mundialmente, a partir das discussões sobre a prevenção criminal e a questão das vitima, no Conselho Social e Econômico das Nações Unidas, quando se elaborou a Resolução no 2002/12 que recomendou aos países a utilização de programas restaurativos em busca da prevenção criminal e do encorajamento de uma Justiça menos punitiva. Os conceitos básicos sobre os princípios da justiça restaurativa enunciados pela resolução são: 
Programa Restaurativo - se entende qualquer programa que utilize processos restaurativos voltados para resultados restaurativos; Processo Restaurativo - significa que a vítima e o infrator, e, quando apropriado, outras pessoas ou membros da comunidade afetados pelo crime, participam coletiva e ativamente na resolução dos problemas causados pelo crime, geralmente com a ajuda de um facilitador. O processo restaurativo abrange mediação, conciliação, audiências e círculos de sentenças; Resultado Restaurativo - significa um acordo alcançado devido a um processo restaurativo, incluindo responsabilidades e programas, tais como reparação, restituição, prestação de serviços comunitários, objetivando suprir as necessidades individuais e coletivas das partes e logrando a reintegração da vítima e do infrator (ECOSOC, 2002).

\subsection{Princípios Restaurativos e Princípios Retributivos}

Howard Zehr, ao publicar em 1990 o livro Changing Lenses, sugere uma ruptura que se torna um paradigma da justiça restaurativa ao dividir o modelo retributivo do modelo restaurativo. Em 1993, L. Walgrave desenvolve uma síntese para a definição de justiça restaurativa, conforme o quadro abaixo:

Quadro 1: os três modelos de justiça de acordo com Walgrave (1993:12)

\begin{tabular}{|c|c|c|c|}
\hline & Penal & Reabilitador & Restaurativo \\
\hline $\begin{array}{l}\text { Ponto de } \\
\text { referência }\end{array}$ & O delito & O delinqüente & Os prejuízos causados \\
\hline Meios & $\begin{array}{l}\text { A aflição de uma } \\
\text { dor }\end{array}$ & O tratamento & A obrigação para restaurar \\
\hline Objetivos & O equilíbrio moral & A adaptação & A anulação dos erros \\
\hline $\begin{array}{l}\text { Posição das } \\
\text { vitimas }\end{array}$ & Secundário & Secundário & Central \\
\hline $\begin{array}{c}\text { Critérios de } \\
\text { avaliação }\end{array}$ & $\begin{array}{l}\text { Uma "pena } \\
\text { adequada" }\end{array}$ & $\begin{array}{l}\text { O indivíduo } \\
\text { adaptado }\end{array}$ & $\begin{array}{c}\text { Satisfação dos } \\
\text { interessados }\end{array}$ \\
\hline Contexto social & Estado opressor & Estado providência & Estado responsável \\
\hline
\end{tabular}

Fonte: Walgrave, 1993, p.12.

Nota-se que o direito restaurador utiliza os danos causados pela infração como ponto de partida, diferentemente do direito penal que utiliza a infração e do reabilitador que toma como posição inicial o delinquente. $O$ direito restaurativo visa a reparação dos prejuízos causados pelos responsáveis pelos erros. Já o direito penal busca o restabelecimento do equilíbrio moral e a justiça reabilitadora procura a adaptação do ofensor através de um determinado tratamento. $\mathrm{Na}$ justiça restaurativa observamos a centralidade da vitima em detrimento de seu 
papel secundário nos outros modelos. Na avaliação, os critérios utilizados pelos modelos também divergem substancialmente assim como o contexto social, no qual o modelo restaurativo se expressa em um contexto responsável, onde os envolvidos no conflito são responsabilizados pelo estado, conforme se vê no quadro acima. Dessa forma, a justiça restaurativa procura o reparo das consequências que surgiram da infração, abrangendo as dimensões materiais, psicológicas e simbólicas, se apresentando com uma imensa pluralidade de objetivos, conforme a definição de Cormier (2002):

"A justiça restaurativa é uma aproximação de justiça centrada na correção dos erros causados pelo crime, mantendo o infrator responsável pelos seus atos, dando diretamente às partes envolvidas por um crime - vitima(s), infrator e coletividade - a oportunidade de determinar suas respectivas necessidades e então responder em seguida pelo cometimento de um crime e de, juntos, encontrarem uma solução que permita a correção e a reintegração, que previna toda e qualquer posterior reincidência"

Algumas diferenças básicas entre o modelo restaurativo e o retributivo devem ser explicitadas para o melhor entendimento das aproximações e afastamentos entre os dois sistemas e assim se perceba quando podem ser complementares e quando se tornam excludentes. De acordo com o entendimento de Pinto (2005:24):

\section{Quadro 2: Valores da Justiça Retributiva x Justiça Restaurativa, segundo Pinto (2005:24)}

\begin{tabular}{|l|l|}
\hline \multicolumn{1}{|c|}{ JUSTIÇA RETRIBUTIVA } & \multicolumn{1}{c|}{ JUSTIÇA RESTAURATIVA } \\
\hline $\begin{array}{l}\text { Conceito estritamente jurídico-normativo de } \\
\text { Crime - Violação da Lei Penal - ato contra a a } \\
\text { sociedade representada pelo Estado - } \\
\text { Unidisciplinariedade }\end{array}$ & $\begin{array}{l}\text { Conceito amplo de Crime - Ato que } \\
\text { afeta a vítima, o próprio autor e a } \\
\text { comunidade causando-lhe uma } \\
\text { variedade de danos - } \\
\text { Multidisciplinariedade }\end{array}$ \\
\hline $\begin{array}{l}\text { Primado do Interesse Público (Sociedade, } \\
\text { representada pelo Estado, o Centro) - } \\
\text { Monopólio estatal da Justiça Criminal }\end{array}$ & $\begin{array}{l}\text { Primado do Interesse das Pessoas } \\
\text { Envolvidas e Comunidade - Justiça } \\
\text { Criminal participativa }\end{array}$ \\
\hline $\begin{array}{l}\text { Culpabilidade Individual voltada para o } \\
\text { passado - Estigmatização }\end{array}$ & $\begin{array}{l}\text { Responsabilidade, pela restauração, } \\
\text { numa dimensão social, compartilhada } \\
\text { coletivamente e voltada para o futuro }\end{array}$ \\
\hline Uso Dogmático do Direito Penal Positivo & Uso Crítico e Alternativo do Direito \\
\hline $\begin{array}{l}\text { Indiferença do Estado quanto às } \\
\text { necessidades do infrator, vítima e } \\
\text { comunidade afetados - desconexão }\end{array}$ & $\begin{array}{l}\text { Comprometimento com a inclusão e } \\
\text { Justiça Social gerando conexões }\end{array}$ \\
\hline
\end{tabular}




\begin{tabular}{|l|l|}
\hline Mono-cultural e excludente & $\begin{array}{l}\text { Culturalmente flexível (respeito à } \\
\text { diferença, tolerância) }\end{array}$ \\
\hline Dissuasão & Persuasão \\
\hline
\end{tabular}

Fonte: Pinto, 2005, p.24.

Sinteticamente, pode- se elencar, da seguinte forma, as principais diferenças entre o modelo retributivo e o restaurativo. Em relação aos procedimentos, destaca-se o ritual solene e publico da Justiça Retributiva, com indisponibilidade da ação penal, linguagem formal, autoridades e profissionais do direito como atores principais contrapondo-se ao sistema Restaurativo, com ritual informal e comunitário, colaborativo, procedimento informal e confidencial, vitimas, ofensores e comunidade como atores principais, processo decisório com participação das pessoas envolvidas. No que tange aos efeitos para vitima, o sistema retributivo dispensa pouca ou nenhuma consideração, essa ocupa lugar periférico e alienado no processo. Já na Justiça Restaurativa, a vítima ocupa lugar central, com voz ativa e é empoderada no processo. Em relação ao infrator, esse raramente participa no modelo Retributivo ao contrário do que ocorre no Restaurativo, onde esse é visto no seu potencial de responsabilizar-se pelos danos causados pela sua infração, interage com a vítima e com a comunidade, se vê envolvido no processo e com possibilidade de contribuir para a decisão. Nota-se que a justiça retributiva apresenta um conceito estritamente jurídico de crime, visto como uma violação penal onde há o monopólio estatal da justiça criminal (PINTO, 2005). Na Justiça Restaurativa temos um conceito mais amplo de crime, no qual o ato afeta a vitima, o próprio ofensor e comunidade circunvizinha, uma noção de crime na qual este é visto como uma transgressão a um código legal, mas também como causador de algumas consequências sociais (DUFF, 2003:12). Essa perspectiva gera uma visão na qual a justiça restaurativa não precisa necessariamente ser uma substituição ao sistema retributivo, mas os sistemas podem ser utilizados complementarmente.

É verdade que as praticas da Justiça Restaurativa encontram determinadas criticas, dentre elas podem ser citadas: o argumento de que se desviaria do devido processo legal, afastando-se das garantias constitucionais e das normas infraconstitucionais e, dessa forma, produziria uma deformação no direito penal legitimo, que tem no principio da legalidade a sua fundamentação 
(PINTO, 2005). Os defensores da Justiça restaurativa afirmam que o modelo, ao priorizar papel da vitima e do infrator no encontro restaurativo, não impede que a vítima e infrator tenham acesso a advogados para se consultarem, nem que se encaminhem para o processo formal.

Outro ponto questionado diz respeito à possibilidade desse novo paradigma banalizar determinados crimes, num retrocesso em relação aos avanços do código penal. Essa crítica é rebatida com o argumento de que um dos requisitos para a admissão do encaminhamento dos envolvidos para 0 processo restaurativo é a voluntariedade e, se a vítima preferir, ela continua podendo acionar o sistema formal. Afirma-se que a justiça restaurativa é incapaz de restaurar a ordem jurídica e não é eficaz na restauração da vitima, fatos que são contrapostos pelo argumento de que a Justiça Restaurativa, como procedimento complementar ao sistema formal, tem a capacidade de recompor a ordem jurídica ao encarar o crime com outra metodologia que gera melhores resultados para a vítima, que recupera a autoestima, a segurança, o controle da situação e a sua dignidade, além de provocar ao infrator a sua responsabilização pelo mal causado e the dar a oportunidade de reparar o erro (PINTO, 2005).

Também se critica o fato de que esse modelo poderia desjudicializar a Justiça Criminal e privatizar o Direito Penal, sujeitando os envolvidos no conflito a um controle ilegítimo de pessoas não investidas de autoridade publica. A esse questionamento, os defensores da Justiça Restaurativa tem afirmado que 0 processo é constitucional e legalmente sustentável, visto que a ocorrência da mediação, conciliação e transação, estão previstos na legislação. Essa metodologia restaurativa, que prima pela participação dos envolvidos no processo decisório, quando for possível e quando for vontade das partes, é legal. Além disso, se afirma que a Justiça Restaurativa só serve para beneficiar o infrator, promovendo a impunidade. Isso é contestado, em primeiro lugar, lembrando que a grande insatisfação que a sociedade apresenta a respeito da impunidade e da leniência do sistema penal, é em relação ao sistema formal, explicitando a ineficácia do mesmo. Também é notória a ineficácia do sistema prisional e sua reserva apenas para crimes graves. Esse sistema já é tido como ultrapassado e a visão de que a prisão é o remédio para a criminalidade se mostra cada vez mais distante da realidade contemporânea. (PINTO, 2005). 
É notório que na justiça penal são observadas grandes atrocidades ante os princípios fundamentais constitucionais, como a liberdade e a dignidade da pessoa humana. O castigo e a violência da punição não tem tido sucesso no combate à criminalidade e acabam por intensificar a violência que atinge os cidadãos. Segundo Focault (2002), a resposta penal fragiliza o protagonismo do individuo em relação à vida ao possibilitar o desenvolvimento de uma autoimagem que assume uma existência sem sentido, formando-se indivíduos que se percebem como partes esparsas do sistema social, sem capacidade de interferência no curso de sua própria história e sem a possibilidade de exercerem sua liberdade. É nesse contexto que as pratica de Justiça Restaurativa surgem como um novo paradigma que visa promover o acesso à justiça e amenizar as falhas e fragilidades do sistema de justiça penal.

Dentre os defensores da Justiça Restaurativa, também encontramos correntes que se aproximam em determinados pontos e se afastam em outros, Jaccoud (2005), define três modelos de justiça restaurativa que exemplificam a complexidade e as divergências dos partidários das práticas restaurativas. São eles: O modelo centrado nas finalidades, denominado maximalista (Walgrave, 1999) no qual a justiça restaurativa está voltada para a correção das consequências, onde as finalidades são prioritárias e os processos utilizados tomam posição secundária, dessa forma, se pode colocar em questão a utilização da arbitragem ou a imposição de sansão restaurativa imposta por um juiz em caso da parte não aceitar a negociação. Outro modelo é o centrado nos processos, no qual o processo é fundamentado na participação das partes e se necessário da comunidade atingida. Esse modelo, apesar de buscar finalidades de cunho retributivo por pregar a negociação e consulta dos envolvidos é considerado por alguns como pratica restaurativa. Por ultimo, Jaccoud (2005) define o modelo centrado nos processos e finalidades que adota uma visão que é mais restrita da Justiça Restaurativa por impor a obrigatoriedade de meios negociáveis e finalidades restaurativas. Isso exige a aceitação e a boa vontade dos envolvidos em participar dos procedimentos, o que restringe a aplicação da Justiça Restaurativa à administração de infrações sumárias reduzindo bastante 0 seu alcance, esse modelo é denominado de perspectiva minimalista (WALGRAVE, 1999). 
O que se percebe é que o modelo baseado no processo, apesar de primar pela negociação, não pode ser considerado um modelo restaurativo ao visar finalidades de cunho retributivo. Já o modelo focado nos processos e finalidades restringe bastante a prática da Justiça Restaurativa, apesar de ser o mais purista, apresenta uma grande limitação na sua abrangência. $O$ modelo centrado nas finalidades parece ser mais abrangente, mais eficaz e mais suscetível de utilização em uma sociedade com uma imensa complexidade de relações sociais e conflitos como a sociedade pós-moderna (JACCOUD, 2005).

De acordo classificação em maximalista e minimalista (WALGRAVE, 1999), se colocam em pauta algumas questões de divergência e aproximação em relação aos procedimentos utilizados nos dois modelos. Em primeiro lugar, os lugares da prática, ponto onde os partidários da Justiça Restaurativa apresentam algumas divergências. Os minimalistas, ou "diversionista do sistema judiciário principal" (Walgrave, 1999) concebem que se deve convocar exclusivamente voluntários que aceitem antecipadamente serem orientados nos processos da justiça restaurativa, essa corrente advoga em prol do afastamento do estado da administração destes processos por entenderem a Justiça Restaurativa como uma alternativa ao sistema de justiça estatal. Já a visão maximalista se opõe a essa perspectiva devido aos limites de sua aplicação e prega que para que haja uma profunda transformação no modelo retributivo, a Justiça Restaurativa deve ser integrada ao sistema estatal (Walgrave, 1999). Dessa forma, a criação de um sistema de justiça estatal que vise à valorização da reparação dos danos causados às vitimas, no qual o ofensor seja convidado a contribuir com essa reparação em detrimento do dano, mesmo que haja um nível elevado de constrangimento e uma imposição de uma sanção reparadora, não pode ser considerado um sistema retributivo. É importante salientar, que para essa corrente o que importa á a finalidade de reparo das consequências e não a percepção dos envolvidos. Segundo Jaccoud, (2005:180):

"Esta posição minimalista inclui limites e riscos, visto que confina a justiça restaurativa à administração de delitos secundários e de incivilidades, e que abre caminho, por si mesma, ao risco de ampliação da esfera penal e até mesmo da intolerância com respeito aos conflitos de toda ordem. A posição maximalista que nós privilegiamos sugere uma transformação das práticas do sistema de justiça e, assim, uma integração dos princípios restaurativos na aplicação do controle sócio-penal, tanto à montante quanto à jusante do sistema de justiça. É neste 
ponto que, no meu entendimento, os contornos da justiça restaurativa permanecem mais fluidos. Esta imprecisão vem de uma incompreensão da perspectiva maximalista. Em uma perspectiva maximalista, o sistema de justiça, mantendo inteiramente seu caráter coercitivo, substitui a finalidade punitiva da sanção por uma finalidade restaurativa."

O lugar da comunidade nos processos restaurativos goza de maior consenso entre os defensores do tema. A comunidade é posta ou como vitima indireta do crime ou como participante na administração dos programas da justiça restaurativa. É importante ficar atento ao perigo de que a inclusão da comunidade se torne uma condição necessária para o procedimento da justiça restaurativa, o que pode levar à definição desse modelo através da obrigatoriedade de participação da comunidade em detrimento do papel central das finalidades reparadoras, centrando-se no processo. (JACCOUD, 2005). Outros dois fatores que geram debates, tanto em relação ao modelo maximalista quanto ao modelo minimalista, dizem respeito, em primeiro lugar, à proporcionalidade, onde críticos do modelo restaurativo afirmam que um conflito pode receber tratamento mais suave ou mais severo nas praticas restaurativas, devido ao alto grau de subjetividade envolvido em cada processo. Em segundo lugar, à extensão da rede penal, que significa que praticas aplicadas visando a redução do recurso ao sistema penal podem acabar contribuindo para aumentar o controle de indivíduos em situações que jamais seriam tratadas pelo sistema penal formal.

Diante desse breve panorama das idéias relativas aos princípios da Justiça Restaurativa, das críticas enfrentadas pelos partidários desse inovador modelo e das divergências internas relacionadas ao desenvolvimento das praticas, percebe-se nitidamente a necessidade de um aprimoramento do sistema de justiça formal, para que a sociedade tenha respostas adequadas à complexidade de suas demandas no se refere à questão da administração de conflitos. Procurando suprir essas necessidades a Justiça restaurativa pode ser vista como uma esperança de novas perspectivas que viabilizem a disseminação do acesso à justiça e a diminuição dos altos índices de violência e criminalidade característicos da sociedade brasileira. 


\subsection{Justiça Restaurativa no Brasil}

A transformação democrática ocorrida no país a partir da década de 1980 promoveu mudanças significativas no ordenamento jurídico brasileiro devido à promulgação de leis que possibilitam a apropriação pelos cidadãos de novos lugares dentro do sistema social, como por exemplo, a Lei das Pessoas Portadoras de Deficiência (1989) ou o Estatuto da Criança e do Adolescente (1990) e a própria Constituição de 1988. Na Carta Magna, o seu artigo 98, I, prevê a possibilidade de conciliação e transação em caso de infrações penais de menor potencial ofensivo, através de procedimentos informais e sumaríssimos, mediante a instituição dos Juizados Especiais, regulamentados pela Lei 9.099 de 1995, reiterada pela lei 10.259/01 e alterada pela 11.313/06 que os destinou a contravenções penais e crimes com pena máxima de dois anos, que tenham o caráter de infração de menor potencial ofensivo. A lei estabelece que os princípios da oralidade, simplicidade, informalidade, celeridade e economia processual devem nortear o procedimento (NUCCI, 2005). O poder decisório nos Juizados Especiais cabe, em ultima instancia, ao magistrado, mas flexibiliza o ordenamento jurídico dando espaço para os valores das partes envolvidas no conflito.

A legislação brasileira passa a apresentar algumas possibilidades e obstáculos para as praticas restaurativas. A Justiça Restaurativa encontra respaldo na legislação em função do principio da oportunidade presente na Constituição Federal de 1988 e na lei 9.099 de 1995, que trouxe inovações processuais de suma importância para o avanço das formas alternativas de resolução de conflitos (PINTO, 2005). Segundo o principio da oportunidade, o ofendido pode propor a ação de acordo com sua conveniência. Esse princípio é aplicado em ações penais privadas e parte da premissa de que o Estado não tem a capacidade de processar todas as pessoas que hajam cometido delitos. A Lei 9.099/95 apresenta uma grande inovação rumo a despenalização ao trazer medidas que afastam a possibilidade de reclusão penal e dão espaço para a participação das partes envolvidas. São elas a composição civil (art. 74 e parágrafo único), a transação penal (art. 76) e a suspensão condicional do processo (art.89), fazendo com que o principio da oportunidade possa coexistir com a obrigatoriedade da ação penal (PINTO, 2006). De acordo com a lei, tanto 
na fase preliminar quanto durante o procedimento contencioso existe a possibilidade de derivação para o processo restaurativo, sendo que, nos crimes de ação penal privada e publica condicionada, é possível a despenalizaçao por extinção da punibilidade via composição civil. Nos casos de ação penal publica pode-se utilizar os encontros entre os envolvidos para se discutir uma sugestão de medida alternativa para a solução do conflito.

Compete à Delegacia de Polícia, normalmente, encaminhar os envolvidos para o Juizado Especial Criminal, quando o fato for classificado como de menor potencial ofensivo, lavrando um Termo Circunstanciado de Ocorrência ao invés de instaurar um inquérito policial. Nos Juizados Especiais Criminais existe para o réu a possibilidade da conciliação, da transação, da suspensão condicional e da substituição da pena. Para que isso ocorra, as partes são conduzidas, em um primeiro momento, para uma audiência de conciliação. Nessa fase do procedimento abre-se uma porta para a utilização das praticas restaurativa, no sentido da promoção da autocomposição penal do conflito. Em caso de ação penal publica ou ação penal privada é possível uma composição civil na qual haja um acordo que possibilite a reparação dos danos morais e materiais decorrentes do conflito, nessa etapa as práticas alternativas também podem ser utilizadas. Em casos de ação penal incondicionada, aquela proposta pelo Ministério Publico com ou sem autorização da vitima, existe a possibilidade do promotor de justiça propor ao infrator a transação da pena por uma pena alternativa restritiva de direitos ou de prestação pecuniária. Assim, se as partes chegarem a um acordo durante a conciliação ou se o ofensor aceitar a transação penal, o juiz homologa o acordo. (Kant de Lima, 2003). Dessa forma, nos termos da lei 9.099/95 existem, em várias fases do procedimento, possibilidades de utilização das praticas restaurativas. Estas podem ser empregadas na construção de uma solução na conciliação e na transação penal a partir do espaço aberto para o consenso, oferecendo respostas mais abrangentes aos danos subjetivos causados pelos conflitos.

As práticas restaurativas também encontram espaço para serem aplicadas por força do art. 91, da Lei 10.741/03, o Estatuto do Idoso, que prevê o procedimento da Lei 9.099/95 para crimes cuja pena privativa de liberdade não ultrapasse quatro anos, nesses casos, após parecer favorável do Ministério publico, seriam indicados para núcleos de Justiça Restaurativa para avaliação e 
preparação para os encontros restaurativos. Após conclusão, os casos retornariam para o Ministério Publico onde a promotoria incluiria as clausulas do acordo restaurativo em sua proposta e encaminharia para a homologação judicial. Passaria, então, à fase executiva, onde se acompanharia o cumprimento do acordo, executando o monitoramento e a avaliação do programa. (PINTO, 2007)

Outra forma de inserção das praticas restaurativas é através da suspensão condicional do processo, instituto utilizado em crimes de pena mínima cominada inferior a um ano. Nesses casos, o juiz pode suspender o processo e submeter o acusado a condições específicas que restringem seu comportamento, de acordo com 0 art. 89 da Lei 9.099/95:

Art. 89. Nos crimes em que a pena mínima cominada for igual ou inferior a um ano, abrangidas ou não por esta Lei, o Ministério Público, ao oferecer a denúncia, poderá propor a suspensão do processo, por dois a quatro anos, desde que o acusado não esteja sendo processado ou não tenha sido condenado por outro crime, presentes os demais requisitos que autorizariam a suspensão condicional da pena (art. 77 do Código Penal).

$\S 1^{\circ}$ Aceita a proposta pelo acusado e seu defensor, na presença do Juiz, este, recebendo a denúncia, poderá suspender o processo, submetendo o acusado a período de prova, sob as seguintes condições: I - reparação do dano, salvo impossibilidade de fazê-lo; II - proibição de freqüentar determinados lugares; III - proibição de ausentar-se da comarca onde reside, sem autorização do Juiz; IV - comparecimento pessoal e obrigatório a juízo, mensalmente, para informar e justificar suas atividades.

$\S 2^{\circ}$ O Juiz poderá especificar outras condições a que fica subordinada a suspensão, desde que adequadas ao fato e à situação pessoal do acusado.

$\S 3^{\circ}$ A suspensão será revogada se, no curso do prazo, o beneficiário vier a ser processado por outro crime ou não efetuar, sem motivo justificado, a reparação do dano.

$\S 4^{\circ}$ A suspensão poderá ser revogada se o acusado vier a ser processado, no curso do prazo, por contravenção, ou descumprir qualquer outra condição imposta.

$\S$ 5ำ Expirado o prazo sem revogação, o Juiz declarará extinta a punibilidade.

$\S 6^{\circ}$ Não correrá a prescrição durante o prazo de suspensão do processo.

$\S 7^{0}$ Se 0 acusado não aceitar a proposta prevista neste artigo, o processo prosseguirá em seus ulteriores termos. (Lei 9.099 publicada em 1995).

Apesar das possibilidades de aplicação das praticas restaurativas, é só em 2004, através do projeto "Promovendo Praticas Restaurativas no Sistema de 
Justiça", da Secretaria de Reforma do Judiciário do Ministério da Justiça, desenvolvido em parceria com o Programa das Nações Unidas para o Desenvolvimento, que a Justiça Restaurativa foi formalmente introduzida no Brasil. Por meio desse projeto, foram viabilizadas a implantação de três projetos pilotos de Justiça Restaurativa. Em Brasília, no Juizado Especial Criminal do Núcleo Bandeirante; em São Paulo, na Vara da Infância e da Juventude da Comarca de São Caetano do Sul; e em Porto Alegre, na $3^{\underline{a}}$ Vara da Infância e da Juventude. Esses projetos deram frutos e hoje se veem iniciativas sendo implantadas, apesar das dificuldades, em alguns estados brasileiros, como Bahia e Maranhão. Na Bahia, por exemplo, através da resolução no08 de 28 de julho de 2010, do Tribunal de Justiça da Bahia, a Justiça Restaurativa foi institucionalizada, contribuindo para a mudança de paradigma e para a reforma do Poder Judiciário. Além disso, atualmente tramita na Câmara dos Deputados, o projeto de lei (PL no 7006/2006), propondo alterações no Código Penal, Código de Processo Pela Lei dos Juizados Especiais, visando se legalizar o uso das praticas restaurativas em casos de alguns tipos de crimes e contravenções penais.

As propostas de implementação de formas não violentas de resolução de conflitos no Brasil encontram apoio em projetos de reformulação do judiciário e em agentes envolvidos com a promoção da paz e da cultura da não violência. No âmbito da reformulação judiciária, esses projetos se apresentam como formas de modernização da justiça visando a ampliação do acesso, redução da morosidade, informalização da justiça e participação mais ativa da comunidade nos processos de resolução de conflitos. (Schuch, 2008). A implantação de tais projetos vem reunindo uma diversa gama de atores sociais, como agentes judiciais, ONGs de proteção aos direitos humanos, professores, lideres comunitários, acadêmicos, etc. Esses agentes formam redes com poderes variados, no que se refere à elaboração de significados sobre os processos e procedimentos. Apesar dessa heterogenia, é possível perceber o aparecimento de um conjunto de discursos hegemônicos que traz noções de autogestão, transformação individual, modernização da justiça e promoção de uma cultura de paz. (Schuch, 2008).

Esses procedimentos representam mudanças, não só no sistema jurídico ao introduzirem praticas associadas à negociação da verdade, mas também tendem a introduzir valores e princípios para a formação de novas subjetividades 
que se caracterizam pela responsabilidade e autonomia individual na gestão da vida. Para Anselm L. Staruss (1999), a formação da identidade dos indivíduos é influenciada de acordo com sua as interações com o mundo. Em suas palavras: "Enquanto perdurar o aprendizado, persistirá a revisão de conceitos; e enquanto ocorrer a revisão, ocorrerá a reorganização do comportamento". Assim, a possibilidade de alteração do espectro de visão de um individuo estará relacionada às experiências das quais este participe e através destas experiências, a forma como o sujeito classifica o mundo e a si mesmo tendem a ser constantemente reavaliada.

Diante dessa realidade, parece explícito que a Justiça Restaurativa pode ser um instrumento de transformação da realidade brasileira, uma ferramenta na construção de uma justiça participativa que consiga suprir as demandas da sociedade por paz social e cidadania. Sabe-se que a justiça restaurativa não vai resolver todos os problemas que se acumulam no sistema jurídico retributivo do Brasil, mas pode ser de grande valia na construção de soluções para esses problemas, segundo Pedro Scuro Neto (2000:102):

"O paradigma da Justiça Restaurativa não representa uma panaceia, um remédio para todos os males do modelo retributivo, mas introduz novas e boas idéias, como a necessidade de a Justiça assumir o compromisso de reparar o mal causado às vítimas, famílias e comunidades, em vez de se preocupar apenas com punir proporcionalmente os culpados." 


\section{3 - PESQUISA DE CAMPO}

\subsection{O Superior Tribunal de Justiça}

O Superior Tribunal de Justiça (STJ) foi criado em 1988, em substituição ao antigo Tribunal Federal de Recursos. Atualmente, é composto por 33 ministros, número mínimo previsto no art. 104 da Constituição Federal. A Composição do Tribunal é por origem, sendo 1/3 (um terço) dos Ministros originários dos Tribunais Regionais Federais, 1/3 escolhido dentre os desembargadores dos Tribunais de Justiça e 1/3 de representantes do ministério público e advogados (50\% para cada categoria). O Presidente da República tem como atribuição a escolha dos Ministros do STJ, a partir de lista tríplice. O escolhido é submetido à aprovação do Senado Federal, por maioria absoluta.

O Tribunal é organizado pelo critério da especialização. As funções administrativas do STJ são exercidas pelo Plenário, integrado pela totalidade dos Ministros da Casa. Três seções de julgamento, cada uma delas composta por duas turmas, analisa e julga matérias de acordo com a natureza da causa submetida a apreciação. Acima delas está a Corte Especial, órgão máximo do Tribunal, que á dirigida pelo presidente do Tribunal e formada pelos 15 ministros mais antigos. Além de algumas funções administrativas, esse órgão julga os processos criminais de competência originária, aqueles que têm início no próprio Tribunal, e dirime questões jurídicas entre os demais órgãos julgadores, como os conflitos de competência entre turmas de seções distintas e os embargos de divergência. Cabe à Corte Especial também aprovar, nos casos que lhe compete, novas súmulas de jurisprudência do STJ, verbetes que resumem o entendimento vigente no Tribunal sobre determinados assuntos, servindo de referência para as demais instâncias da Justiça brasileira. No STJ, as súmulas são aprovadas pela Corte Especial ou por qualquer das suas três seções.

Existem três seções especializadas de julgamento no STJ. Cada seção é formada por duas turmas especializadas, e cada turma é integrada por cinco ministros. A Primeira Seção, composta por ministros da Primeira Turma e da Segunda Turma, aprecia matérias de Direito Público, com destaque para questões administrativas e tributárias, mandados de segurança contra ministros 
de Estado, entre outros temas. A Segunda Seção, composta por ministros da Terceira Turma e da Quarta Turma, decide sobre matérias de Direito Privado, examinando questões de Direito Civil e Comercial. Já a Terceira Seção, composta por ministros da Quinta Turma e da Sexta Turma, julga causas que envolvam matérias de Direito Penal, como habeas-corpus, bem como questões previdenciárias, mandados de segurança contra ministros de Estado e matérias de Direito Público e Privado não cobertas pela Primeira e Segunda seções. É nas seções especializadas que são julgados os processos de competência originária do STJ, aqueles que têm início no próprio Tribunal. São exemplos de processos originários os mandados de segurança, as ações rescisórias, os conflitos de competência e, ainda, os embargos de divergência, que buscam uniformizar a interpretação do Direito entre as turmas de uma mesma seção, quando estas divergirem. Nos casos em que há divergência de interpretação entre turmas de diferentes seções, o exame da questão é remetido à Corte Especial.

Cada uma das três seções de julgamento do STJ é formada por duas turmas especializadas. Cada turma é integrada por cinco ministros. É nas turmas de julgamento do STJ que são apreciados os recursos especiais, as medidas cautelares e os agravos de instrumento e regimentais, bem como casos específicos de habeas-corpus, entre outros. Quando há divergência de interpretação do Direito entre as turmas de uma mesma seção, os feitos são remetidos à respectiva seção. Nos casos em que há divergência de interpretação entre turmas de diferentes seções, o exame da questão é remetido à Corte Especial do STJ. As turmas reúnem-se com a presença de, pelo menos, três ministros. Têm prioridade de julgamento as causas criminais, havendo réu preso, e os habeas-corpus.

De acordo com o art. 105 da Constituição Federal de 1988, o Superior tribunal de Justiça tem as seguintes competências:

Competência originária:

a) nos crimes comuns, os governadores dos Estados, e do Distrito Federal. Nos crimes comuns e de responsabilidade os desembargadores dos Tribunais de Justiça dos Estados e do Distrito Federal, os membros dos Tribunais de Contas dos Estados, do Distrito Federal e dos Municípios (onde houver), os dos Tribunais Regionais Federais, Eleitorais e do Trabalho, os membros do Ministério Público da União que oficiem perante Tribunal. 
b) Os mandados de segurança e habeas corpus contra ato de Ministro de Estado, dos Comandantes da Marinha, Exército e Aeronáutica ou do próprio Tribunal.

c) Habeas corpus quando o coator ou paciente, for governador de Estado ou do Distrito Federal, os Tribunais de Justiça e seus desembargadores, os Tribunais Regionais e seus juízes desembargadores, Os Tribunais de Contas estaduais, distritais ou municipais e seus membros, o Ministério Público da União e seus membros que oficiem em Tribunal Federal.

d) Os conflitos de competência entre quaisquer Tribunais, com exceção dos de competência do STF, bem como entre tribunal e juízes a ele não vinculados e entre juizes vinculados a tribunais diversos. (A Suprema Corte já decidiu que conflito de competência entre Ministério Público Federal deve ser julgado pelo STF).

e) As revisões criminais e ações rescisórias do próprio STJ.

f) A reclamação para preservação da competência do próprio STJ e garantir a autoridade de suas decisões, as demais hipóteses de reclamação são julgadas do STF.

g) Os conflitos de atribuições entre autoridade administrativa e judiciária da União, ou entre autoridades judiciárias de um Estado e administrativa de outro ou do Distrito Federal, ou entre as deste e da União.

h) Mandado de Injunção, quando a elaboração for atribuição do órgão, autoridade federal, da administração direta e indireta, com exceção dos casos que são competência do STF e órgãos da Justiça militar, trabalhista, eleitoral ou da justiça federal.

i) Homologação de sentenças estrangeiras e a concessão de exequatur às cartas rogatórias - Competências incluídas com a Reforma do Judiciário (EC 45/2004). Essa competência anteriormente era do STF.

Competência em Recurso Ordinário: o STJ tem competência para julgar recurso ordinário nos seguintes casos:

a) Os habeas Corpus decididos em única e última instância pelos Tribunais Regionais Federais ou pelos Tribunais dos Estados, Distrito Federal e Territórios, quando a decisão for denegatória. 
b) Os mandados de segurança decididos em única e última instância pelos Tribunais Regionais Federais ou pelos Tribunais dos Estados, Distrito Federal e Municípios, quando a decisão for denegatória.

c) As causas em que forem partes Estado estrangeiro ou organismo internacional, de um lado, e, do outro, Município ou pessoa residente ou domiciliada no país.

Competência em Recurso Especial: as causas decididas, em única ou última instância, pelos Tribunais Regionais Federais ou pelos Tribunais dos Estados, do Distrito Federal e Territórios, quando a decisão recorrida:

a) Contrariar Tratado ou Lei Federal, ou negar-Ihes vigência.

b) Julgar válido ato de governo local contestado em face de lei federal.

c) Der a lei Federal interpretação divergente da que the haja atribuído outro tribunal. As decisões proferidas nos juizados especiais não são passíveis de impugnação pela via do recurso especial. No entanto a Lei 10259/2001 prevê que o STJ tem competência para uniformizar o entendimento jurisprudencial da Turma de Uniformização Nacional.

\subsection{Dificuldades enfrentadas pelo Poder Judiciário em relação às} causas penais.

Dados do Conselho Nacional de Justiça (CNJ) divulgados em 2011 demonstram a alta taxa de congestionamento da Justiça brasileira. Embora tenha recebido menos processos em 2010 do que em 2009, o número de casos sem solução aumentou. De acordo com o relatório da "Justiça em Números", do CNJ, a taxa de congestionamento dos tribunais aumentou de $67 \%$, em 2009, para $70 \%$, em 2010. Isso demonstra que de cada 100 processos em tramitação, 70 não foram solucionados ao longo do ano. Em 2010, 83,4 milhões de processos tramitavam nas cortes brasileiras, um aumento de $0,6 \%$ superior ao total verificado em 2009. Ao longo do ano de 2010, 24,2 milhões de novas ações ingressaram nos tribunais, o que representa uma queda em relação aos números de 2009, quando mais de 25 milhões de ações foram protocoladas. A Justiça Estadual responde por 17,7 milhões dos processos recebidos em 2010, contra 3,2 milhões da Justiça federal e 3,3 milhões da Justiça trabalhista. 
A morosidade constatada nos relatório do $\mathrm{CNJ}$ é relatada pela maioria dos entrevistados no STJ como um impedimento para a efetiva prestação jurisdicional. Como fatores responsáveis pela demora da Justiça em atender a demanda da população, foram citados dois tipos de problemas que podem ser agrupados em: problemas de estrutura e problemas relativos à legislação. Com relação à estrutura, a falta de Juízes foi o ponto mais enfatizado pelos entrevistados, problema que ocorre, principalmente, nos Tribunais Estaduais que, conforme se percebe no levantamento do $\mathrm{CNJ}$, é onde há a maior demanda. Em 2010, segundo o CNJ, o Brasil tinha 16.804 magistrados, numero inferior à média de juízes de países como Itália e Espanha. Além desse fator, em algumas entrevistas foi relatada a falta de equipamentos e a precária infraestrutura em alguns Tribunais Estaduais, além do pouco investimento em tecnologia e treinamento como fatores impeditivos à celeridade da atividade Judiciária, conforme se nota nas palavras do Assessor 1: "A dificuldade estrutural, é decorrente de problema de falta de pessoal, de equipamento, não só nos Tribunais Superiores, mas desde a base...". Preocupação também demonstrada pelo Ministro 1:

"Eu acho que a maior dificuldade é a falta de estrutura material e humana, sem contar o problema da diversidade do país, você tem um país hoje em que são várias as realidades, consequentemente você tem dispositivos legais que são inócuos, não se aplicam [...] No papel a estrutura está toda montada, falta conseguir transferir isso pra pratica. Eu acho que a grande dificuldade é o problema humano e material, sendo que o humano, com essa loucura de processos que nós temos hoje em dia, o próprio Judiciário não tem tempo de se aprofundar na adoção de novas medidas, você precisa, para determinadas idéias, de ter tempo, precisa sentar, conversar, analisar."

No grupo de problemas relatados pelos entrevistados, relativos aos obstáculos oriundos da ineficácia da legislação vigente, foram reiteradas as reclamações a respeito da morosidade do processo penal resultante das possibilidades protelatórias presentes no Código de Processo Penal, segundo o Assessor 2:

"O processo penal é muito lento, o código é muito anacrônico, da época da ditadura e tem um procedimento que está fora de compasso com os tempos de hoje em dia [...] Aquele cara que tem um bom advogado consegue retardar o curso do processo enquanto aqueles que não tem advogados caem naquela "vala" de um processo quase que sem defesa ou com uma defesa patrocinada de forma meramente formal, criando injustiças. Além 
da morosidade, você beneficia o individuo que tem condições de arcar com um bom advogado"

Outro ponto destacado pelos entrevistados, de grande importância para a análise aqui desenvolvida, diz respeito às defensorias públicas, apesar de não fazerem parte do Poder Judiciário. Os defensores públicos são indispensáveis no que tange a temática do acesso à justiça e o que se percebe é que a Defensoria Publica tem uma estrutura insuficiente para o atendimento da demanda. No Ceará, por exemplo, em 2007, para um estado dividido em 184 (cento e oitenta e quatro) municípios o número de defensores públicos era pouco mais de 200 (MINISTÉRIO PUBLICO DO ESTADO DO CEARÁ), numero discrepante em relação às necessidades da população. Segundo o Assessor 3 :

\begin{abstract}
"Você precisa ter uma estrutura melhor dentro do Sistema Judiciário Penal [...] Nós temos vários "Brasis", aqui na capital temos uma boa estrutura, em estados do nordeste a situação é caótica, a gente pega decisões, vê processos que não tem a menor condição de acontecer, processos em que se passam dez anos e não há uma decisão [...] Há uma grande quantidade de pessoas sendo defendidas pela Defensoria Publica e às vezes, o defensor publico mal tem condições de ir às audiências, de fazer as audiências para essas pessoas."
\end{abstract}

Ainda em relação aos pontos que se afastam das atividades especificas do Judiciário, mas exercem grande influencia no desenvolvimento das mesmas, foi repetidamente relatada pelos entrevistados a ineficiência da polícia como um fator causador da inacessibilidade à Justiça. Segundo O Assessor 2:

\footnotetext{
"Uma dificuldade diz respeito à falta de estrutura, a começar pelas delegacias de policia, em uma fase pré-processual, se você for ver os levantamentos de $\mathrm{CNJ}$, a maioria dos inquéritos que são instaurados não são concluídos, conseqüentemente não dão origem a uma ação penal, ou seja, a maior parte dos crimes ficam sem serem investigados e sem serem solucionados. "
}

A morosidade e ineficiência da Justiça são percebidas pela população que se sente desamparada e incrédula. Em maio de 2011 foi divulgado o resultado de uma pesquisa desenvolvida pelo Instituto de Pesquisas Econômicas Aplicadas sobre a percepção social da Justiça no Brasil. Foram pesquisadas 2770 pessoas em todas as regiões do país e segundo Fábio de Sá e Silva, coordenador da pesquisa: "A avaliação, de um modo geral, é bastante negativa e generalizada 
entre a população brasileira". Diante da pergunta: De zero a dez, que nota você daria para a Justiça Brasileira? A média nacional foi de 4,5, não havendo grandes diferenças devido à classe social, raça, grau de escolaridade ou sexo dos entrevistados. Na opinião de quem já acessou a Justiça, a média cai mais ainda, passando para 3,7, de acordo com os dados colhidos pelo IPEA. Foram analisadas: a rapidez na decisão dos casos, facilidade no acesso, baixo custo, capacidade de produzir decisões boas e justas, honestidade e imparcialidade. $\mathrm{Na}$ percepção dos participantes, o quesito honestidade recebeu a pior nota, 1,17 em uma escala de 0 a 4 , imparcialidade e rapidez nas decisões tiveram a nota de 1,18. Custo ficou com a média de 1,45, facilidade no acesso 1,48 e o quesito mais bem avaliado foi o da capacidade da Justiça produzir decisões boas, que ajudem a resolver os casos de forma justa, com 1,60 de média.

Dentro desse contexto de insatisfação e desconfiança em relação à atuação do Poder Judiciário, é explicita a necessidade do desenvolvimento de novas formas eficazes de resolução de conflitos. Frente a essa situação, a Justiça Restaurativa emerge como possibilidade de ser parte da construção de soluções para os impedimentos e anacronias do nosso Estado de Direito Punitivo. Um novo paradigma para se pensar os conflitos e como esses devem ser administrados visando o efetivo acesso à Justiça pela população.

\subsection{A Justiça Restaurativa na percepção dos entrevistados}

Segundo Pedro Scuro Neto (2004), intelectuais e estudiosos do Direito encaram o sistema de Justiça como "um paciente sofrendo uma crise de identidade" causada pelas contradições de uma cultura jurídica calcada na "racionalidade tecnicodogmática", na "retórica da neutralidade" e em procedimentos lógico-formais. A Justiça brasileira é incapaz de acompanhar as transformações sociais e a complexidade e especificidades dos novos conflitos sociais. O Judiciário é visto como:

"órgão burocrático, desatualizado e inerte, de perfil fortemente conservador e de pouca eficácia na solução rápida e global de questões emergenciais vinculadas, quer às reivindicações dos múltiplos movimentos sociais, quer aos interesses das maiorias carentes de justiça e da população privada de seus direitos" (Wolkmer, 2004). 
Adorno também trata da questão e, de acordo com o autor, entre os operadores do direito:

"salvo exceções, predominam os interesses mais conservadores no tocante ao controle da ordem social, à contenção repressiva dos crimes e ao trato nas questões de segurança pública. Assim predomina a desconfiança em relação às soluções alternativas ao contrário, enfatizam as políticas retributivas, que apliquem maior rigor punitivo, se possível concentradas em penas restritivas de liberdade" (ADORNO, 2000: 149).

Durante as entrevistas foram percebidos alguns fatores permeiam a visão dos entrevistados a respeito da temática da Justiça Restaurativa e coadunam com alguns pontos das análises de Scuro Neto e Adorno, no que se referem à inércia do Poder Judiciário, seu conservadorismo e sua incapacidade em ser protagonista de grandes mudanças. Em primeiro lugar, durante as entrevistas, notou-se certa confusão em relação ao conceito, visto que a maioria dos entrevistados associou o termo Justiça Restaurativa a penas alternativas. Vale lembrar que no Conselho Social e Econômico das Nações Unidas quando elaborou a Resolução no 2002/12, recomendando a utilização de programas restaurativos definiu que se entende por programas restaurativos, programas que utilizem processos restaurativos visando resultados restaurativos e que a simples aplicação de penas alternativas não se encaixa em tal modelo. Percebeu-se, ainda, uma falta de conhecimento mais consolidado sobre o tema, tendo os entrevistados, em sua grande maioria, demonstrado algumas pré-noções que se relacionam apenas parcialmente com as praticas restaurativas, conforme se percebe nas palavras do Assessor 4, quando questionado se já teve algum contato com o tema:

"É mais no âmbito acadêmico, na prática eu já atuei perante a justiça de primeiro grau, Defensoria publica, no Supremo Tribunal Federal e aqui no STJ e na prática não há preocupação com essa Justiça Restaurativa, com a vitima, é uma visão acadêmica".

Essa percepção dos entrevistados, de que o modelo restaurativo é um conhecimento que ainda está restrito ao campo teórico e acadêmico e não uma ferramenta pronta para ser utilizada na resolução dos conflitos foi recorrente, segundo o Assessor 1:

"Eu acho que é uma Justiça ainda bastante incipiente, uma iniciativa que ainda está dando os primeiros passos, isso ainda 
demanda um juízo bem grande de valores, um estudo bem aprofundado para saber até que ponto pode ser viável"

Em relação ao modelo Restaurativo, conforme definido pelos autores que embasam esse trabalho, as representações dos entrevistados seguiram, na maior parte das vezes, uma mesma direção. Notou-se certo receio no que se refere à legitimidade das praticas, os entrevistados enfatizaram a necessidade da participação do Estado para que sejam aceitas como legitimas. Para Pinto (2005), dentre as críticas comuns ao modelo de Justiça Restaurativa, tem-se a opinião de que tais práticas poderiam desjudicializar a Justiça Criminal, sujeitando os envolvidos em determinado conflito a um controle ilegítimo de atores que não estão investidos de autoridade publica, ao que os defensores da Justiça Restaurativa respondem afirmando que o processo é constitucional, visto que a mediação, conciliação e transação estão previstos na legislação. Para a defensora Publica Andrea Tourinho P. de Miranda(2010):

"Um dos maiores obstáculos dos operadores do direito em aceitar a Justiça Restaurativa, além da falta de sensibilidade por parte das autoridades, é o medo pela não observância dos direitos fundamentais, precipuamente aos princípios reguladores do Direito Penal e do Direito Processual Penal"

Segundo Renato Souza Pinto (2008), existe um conjunto de normas indisponíveis de direito penal e processual penal que estão expressos em normas e princípios atrelados a direitos e garantias fundamentais indisponíveis que levam os operadores do direito a impossibilidade legal do desvio do curso do processo penal para um meio alternativo, o que gera certo receio em relação aos procedimentos restaurativos. Corroborando com essa noção, o Assessor do Ministro 5 ressalta:

"Eu acho complicado a instituição de um Sistema de Justiça Restaurativa, retirando a competência do Ministério Publico na ação penal já que a competência constitucional é do MP."

É indispensável que o procedimento restaurativo não contrarie os princípios e regras constitucionais e infraconstitucionais, não viole o principio da legalidade em sentido amplo. O procedimento deve respeitar as condições legais para que sua existência seja reconhecida e, assim, tenha vigência e eficácia jurídica. Sem essa observância, o procedimento e seus atos serão inexistentes, ineficazes ou nulos, inaptos para gerar efeitos no mundo jurídico. (PINTO, 2008) 
Outra barreira a ser transposta para a difusão da Justiça Restaurativa no Brasil, diz respeito a uma perspectiva mais subjetiva relacionada aos obstáculos criados por parte do Estado em aplicar medidas alternativas devido ao fato de que a justiça penal tradicional corresponde a uma imposição unilateral da norma positiva que, impregnada de formalismo, vê na pena constritiva de liberdade uma manifestação de autoridade do Estado e o único instrumento possível na resolução de conflitos. (BRANDÃO, 2010). Esse obstáculo foi notado na maioria das entrevistas, seja como discurso de que o Estado é o responsável pela manutenção da ordem e deve assegurar a integridade e coesão social ou no discurso de uma barreira cultural, na qual a população anseia pela punição e o Estado deve atender a tal anseio. Nas palavras do Assessor 6, por exemplo:

"Quando se fala de um homicídio, por exemplo, é claro que não se esquece que ali tem uma família, um interesse particular na solução, porém a apuração e punição daquela conduta é função do Estado. O bem tutelado está acima do interesse particular, isso é um interesse da sociedade, manter as pessoas com sua integridade física, vai muito alem do interesse da própria família."

E do Ministro 3:

"Com relação ao crime, o problema todo é que no crime o Estado é que é detentor do "jus puniende", o direito de punir. Então nós, com isso (Justiça Restaurativa) estaríamos afastando esse "jus puninde", fazendo com que fosse diluído no meio da própria vitima, dos próprios cidadãos, o direito de punir do Estado e eu não acho que é fácil isso aí. [...] Agora, abstrair a presença do Poder Judiciário, abstrair a presença do jus puniende, isso me parece muito difícil."

$\mathrm{Na}$ opinião do Assessor 1, pode-se perceber essa barreira, que no discurso do entrevistado se apresenta como uma necessidade cultural pela retribuição:

"Eu acho que pra realidade brasileira, a Justiça Restaurativa ainda não faz sentido ou não tem condições de ser aplicável porque a nossa cultura, a nossa sociedade entende que a pena, necessariamente, tem que passar por uma fase retributiva, por uma fase que seja claramente punitiva e a gente tem dificuldade de reconhecer como punição a metodologia da justiça restaurativa"

E nas palavras do Ministro 3:

"Em primeiro lugar, o nosso povo não está preparado para mentalmente para isso. Não consciência para a Justiça Restaurativa, ou seja, o cidadão que é ofendido na sua honra, 
que é ofendido na sua integridade, ele não quer saber de nada, ele quer se ver longe do réu. Quer a lei do Tailão, ao mal do crime o mal da pena."

\section{Opinião que também é corroborada pelo Assessor 2,}

"Agora, é uma mudança de mentalidade radical, eu acho que vai encontrar muitas barreiras, até pela opinião publica, pelo parlamento. A resposta que a gente vê hoje em dia por demanda de Justiça, geralmente a resposta é outra. È recrudescer, é mais pena, mais criminalização e essa modalidade (restaurativa) vai na contra mão."

\section{E pelo Assessor entrevistado 6:}

"Lidar com as condutas criminais é lidar com as condutas mais avessas à sociedade, então por si só ela já tem uma carga pesada, as pessoas que são vitimas de um crime, elas querem que o criminoso apodreça na cadeia"

É interessante notarmos que, apesar desse discurso, a maioria dos entrevistados afirma que a pena privativa de liberdade não atinge seus objetivos na contenção da criminalidade nem na ressossialização dos detentos, conforme se as palavras do Ministro2:

"Quando a pessoa pratica um crime, vem a nossa ineficiência na punição daquele infrator, porque hoje a lei de execução penal tem o objetivo principal que é de ressocializar o preso, prender por prender, só como punição pela pratica da infração, sem se preocupar com a ressocialização não tem nenhum sentido."

\section{E do Ministro 3:}

"O problema é a execução penal, o problema do direito penal é a execução penal, não temos presídios suficientes, não temos formas de recuperar os presos [...] Eu lamento porque nós do Judiciário muitas vezes não temos condição de vermos lá como é que é feita a execução, mas já sabemos que há muitos problemas, nos presídios, na educação dos próprios guardas previdenciário, a corrupção que reina nisso, a falta de trabalho para o preso que é o maior problema, na minha opinião."

Fato reiterado por parte da literatura que trata da temática. Segundo Eugenio Raul Zaffaroni (2005:204):

"A pena (...), como instrumento órfão de racionalidade, há vários séculos procura um sentido e não o encontra, simplesmente porque não tem sentido a não ser como manifestação de poder. Portanto, pena é qualquer sofrimento ou privação de algum bem ou direito que não resulte racionalmente adequado a algum dos modelos de solução de conflitos dos demais ramos do direito" 
Apesar dos obstáculos acima descritos, quando informados com maior clareza dos valores restaurativos os entrevistados demonstraram estar abertos a novas perspectivas de resolução de conflitos e foram receptivos com a possibilidade de aplicação do modelo restaurativo a determinados tipos de causas penais. Vale lembrar que, no que tange os valores da justiça restaurativa, é de suma importância a inclusão das partes envolvidas, reconhecendo seus interesses e aceitando seus pontos de vistas em um processo que promove 0 encontro e propicia aos atores envolvidos a chance de determinação da reparação. A inclusão: oportunidade de "envolvimento direto e completo de cada uma das partes." (Van Ness and Strong, 2002: 126) A reparação: chance de reparar o que foi feito, o encontro: oferta de contextos em que as partes possam decidir o que é relevante na discussão de um problema, afastando-se da perspectiva do sistema de Justiça penal que "separa as partes, limita seu contato, reduzindo o conflito a uma escolha binária de culpado/ inocente, considerando irrelevante toda informação que não prove ou confirme diretamente os elementos legais de uma acusação" (Van Ness and Strong2002:77) e a reintegração: dando oportunidade de evitar a estigmatização, devem guiar as praticas restaurativas para que essas atinjam seus objetivos na resolução dos conflitos.(PINTO, 2008) $\mathrm{Na}$ visão de Braithwaite (2002) entre os valores primordiais das praticas restaurativas estão o "diálogo respeitoso", o ambiente "democrático" e a "nãodominação" (2002: 14-15).

A receptividade dos entrevistados à possível aplicação de praticas restaurativas, ainda que tenham uma visão, por vezes receosa e superficial do tema, foi relativamente positiva. Em grande parte das respostas foi dito que, em determinadas causas, o desenvolvimento de novas formas de resolução de conflitos seria de grande valia para a diminuição do numero de processos no Judiciário e para a disseminação do acesso à Justiça. Conforme Assessor 4:

"Eu acho que, a gente vê pela própria experiência pratica que a gente tem, que muitas demandas criminais, elas não necessitariam de um processo criminal, nem muito menos de uma pena. Eu acho que para a criminalidade de menor reprobabilidade, seria assim: Alguns crimes contra o patrimônio, crimes contra a honra e uma serie de delitos culposos, eu acho que não seria necessário essa juducialização, acho que essas medidas seriam mais efetivas (restaurativas), você desonera o Estado de perder tempo com questões que não precisavam estar 
ali e transfere essas (resoluções) para outras esferas do Estado ou da Sociedade."

\section{E de acordo com as palavras do Ministro 1:}

"Eu acho que é o caminho que o Brasil tem que seguir (da Justiça Restaurativa), não só no campo penal, mas também no campo civil. Eu tenho falado isso a algum tempo, eu tenho hoje no gabinete quase 10.000 processos conclusos, sem contar os que estão andando pelo Tribunal. É humanamente impossível você julgar todos esses processos. Ainda mais contando que todo mês entram mil, mil e poucos processos. Você tem que diminuir a quantidade de processos. $E$ não é restringindo recurso, restringindo o direito do advogado. Isso é um dos procedimentos. Então, você tem que mudar a mentalidade do juiz, a mentalidade dos advogados e a mentalidade das partes e a questão da Justiça Restaurativa é um passo pra isso"

\section{E nas palavras do Ministro 2:}

"Estamos vivendo um momento de busca por soluções para a criminalidade, fora dos presídios, com menos burocracia, menos morosidade e com mais Justiça e sensibilidade social. Isso porque, a olhos vistos, o modelo que aí está não está funcionando"

\section{E nas palavras do Ministro 3:}

"Nós estamos naquela fase hoje em dia, no inicio, e eu acho que é valido tentar aproximar vitima e réu, porque tradicionalmente o papel da vitima foi muito secundário, especialmente nos chamados crimes contra a pessoa [...] Eu acho que são validos os esforços no sentido dessa Justiça Restaurativa, que visa dar mais enfoque para o réu [...] uma visão mais humanista."

A Justiça Restaurativa, na visão dos entrevistados, seria, então, uma alternativa aplicável no tratamento de causas penais, sendo que a maioria acredita na aplicação, especificamente, nas causas de infrações de menor potencial ofensivo. Conforme disse se percebe na resposta do Ministro 2:

"Aliás, indo mais longe, acredito que muitos conflitos na esfera criminal, que envolvem crime de "bagatela" por exemplo, não deveriam sequer bater às portas do Poder Judiciário, cabendo aí, a utilização dos métodos da Justiça Restaurativa"

E o Ministro 3:

"Eu acho que há espaço sim, tem espaço, mas para crimes menos graves, para crimes mais graves tem que haver mais conscientização da população, mais preparo nosso [...] Naqueles crimes em que pode ser transmutada a pena de privativa de liberdade para restritiva de direito." 
Vale ressaltar a constituição de 1988 prevê a possibilidade de conciliação e transação penal em causas de menor potencial ofensivo e após a decretação da Lei 9.099 de 1995 - reiterada pela lei 10.259/01 e alterada pela 11.313/06 foi regulamentada a existência obrigatória dos Juizados Especiais Criminais destinados a essas causas. Segundo a lei 11.313/06:

Art. 60. O Juizado Especial Criminal, provido por juízes togados ou togados e leigos, tem competência para a conciliação, o julgamento e a execução das infrações penais de menor potencial ofensivo, respeitadas as regras de conexão e continência.

Parágrafo único. Na reunião de processos, perante - juízo comum ou o tribunal do júri, decorrentes da aplicação das regras de conexão e continência, observarse-ão os institutos da transação penal e da composição dos danos civis. (NR)

Art. 61. Consideram-se infrações penais de menor potencial ofensivo, para os efeitos desta Lei, as contravenções penais e os crimes a que a lei comine pena máxima não superior a 2 (dois) anos, cumulada ou não com multa. (NR)

Durante a análise das entrevistas ficou claro que o conhecimento dos entrevistados sobre o tema da Justiça Restaurativa ainda é muito superficial e para que seja satisfatória a intervenção dos operadores jurídicos nas praticas restaurativas é importante que seja acompanhada de uma capacitação específica e de uma sensibilização para lidar com os conflitos guiados por essas praticas. Essa mudança exige a convivência com o "pluralismo jurídico, com o senso jurídico comum e com o compartilhamento de decisões com a vitima, o infrator e as pessoas das famílias e comunidades - os verdadeiros donos do conflito". (PINTO, 2008:190).

De qualquer forma, tendo em vista a receptividade dos entrevistados, com raras exceções, notou-se que de acordo com suas perspectivas os Sistemas Retributivo e Restaurativo podem ser complementares. É importante salientar que - Sistema Restaurativo não visa substituir as maneiras formais de acesso ao Judiciário e sim, ser um mecanismo complementar na gestão dos antagonismos de interesses presentes nas sociedades (PINTO, 2008). A Justiça Restaurativa não tem o intuito de substituir o sistema de justiça tradicional, é um complemento, e muito menos tem a missão a resolver a todos os problemas da Justiça Brasileira. $\mathrm{Na}$ percepção dos entrevistados é possível essa aplicação 
concomitante de ambos os sistemas conforme se percebe nas palavras do

Assessor 5:

"Tem que se tentar ver soluções que dêem mais praticidade ao nosso sistema (de justiça penal), então acho que essas praticas vão ser completamente complementares ao nosso sistema comum, que temos hoje em dia"

E de acordo com o Ministro 1:

"Essa forma de aproximar a vitima do delinqüente, de sentar e tentar achar um denominador comum, achar uma solução amigável, não só no aspecto civil, mas também no aspecto penal, eu acho altamente positivo. [...] eu acredito que os Sistemas podem ser complementares acho que há espaço no campo jurídico, hoje você tem dispositivos legais que permitem essas praticas, mas não na sua plenitude, você tem (dispositivos) pontuais, você tem no Estatuto do Menor, ECA, no Juizado Especial, você tem no próprio código penal, mas como medidas alternativas, que não necessariamente passam por uma negociação, muitas vezes ficam condicionadas a vontade do juiz. É um embrião e eu, particularmente, acho que o ideal é que seja assim. Você não pode fazer uma mudança dessa, uma mudança de mentalidade, de pensamento, sem saber se isso dá resultado. O problema é que você tem que tornar isso que já se sugere na legislação em vigor uma realidade e para isso você vai ter que estruturar a magistratura, o Ministério Publico, os advogados, pra esse tipo de solução. Você tem que divulgar, tornar isso uma iniciativa rotineira, costumeira. Isso não pode ficar uma solução de um juiz que resolve incentivar isso, tem que sair de uma iniciativa de cima pra baixo que incentive o juiz a caminhar nesse sentido" 


\section{CONSIDERAÇÕES FINAIS}

A temática da democratização do acesso à Justiça através da implementação de formas alternativas de resolução de conflitos vem ganhando espaço nos âmbitos acadêmico, civil e governamental do país. Esse debate está permeado pela necessidade de tornar as instituições mais acessíveis e de oferecer soluções eficazes para os conflitos sociais, demanda que não vem sendo suprida pelo Sistema de Justiça Formal. A lenta resposta das instituições às demandas sociais, no que diz respeito a soluções satisfatórias aos obstáculos existentes ao efetivo acesso à justiça, faz emergirem novas formas de administração de conflitos que apresentam possibilidades de superação das deficiências do Estado de Direito Punitivo. A adoção dessas formas alternativas surge como um novo caminho para a oferta de diferentes soluções aos conflitos e de democratização do acesso à justiça, fortalecendo o tecido social.

È importante que as formas de resolução de conflitos dêem a devida importância aos aspectos subjetivos da violência. Sendo os danos materiais e físicos considerados mais importantes, os danos morais e psicológicos, característicos dos conflitos interpessoais, acabam recebendo um tratamento mais condescendente por parte das instituições judiciárias. A dificuldade de mensuração dos danos mais relacionados às subjetividades dos indivíduos, além de sua ocorrência cotidiana e sua pequena relevância jurídica, geram, por vezes, a banalização desse tipo de violência. Segundo (COSTA \& BANDEIRA, 2007) observa-se, então, o escamoteamento dos conflitos interpessoais e a intensificação das animosidades que acabam por gerar práticas violentas. Embora ocorram no domínio privado e tenham um menor apelo social, as violências decorrentes dos conflitos interpessoais são uma grave ameaça à paz social (SUAREZ, 2002).

São grandes os perigos gerados por essa invizibilação dos conflitos interpessoais sendo indispensável o reconhecimento das representações sociais dos indivíduos para a efetiva administração de seus conflitos (SIMMEL, 1983). Determinadas práticas sociais, ao negarem ou escamotearem os conflitos interpessoais, não impedem a continuidade das hostilidades entre os sujeitos. Estas subjetividades negadas ou encobertas podem ser transferidas para outros objetos ou podem acabar se transformando em indisposições sociais, por vezes, 
mais intensas ou violentas. Para uma administração satisfatória, torna-se indispensável o entendimento do conflito em toda a sua complexidade material e simbólica e o reconhecimento das perspectivas das partes envolvidas, considerando os interesses que causaram a disputa e os danos gerados às partes e à sociedade, sejam eles materiais e/ou simbólicos.

Dentro desse escopo, a Justiça Restaurativa surge como uma nova maneira de se pensar os conflitos. Uma forma de intervenção que, ao trazer noções de autogestão, transformação individual, modernização da justiça e promoção de uma cultura de paz. (Schuch, 2008), tende a impedir que tais conflitos tenham desfechos violentos. A o fazer com que o conflito seja pensado como uma violação às relações sociais, as praticas restaurativas buscam o restabelecimento dos relacionamentos atingidos pelos conflitos e não só a punição de quem infringiu determinada lei. Dessa forma, ao procurar a reparação dos danos ao invés da simples punição dos culpados, tendo como principio o protagonismo das partes envolvidas, as soluções restaurativas abrangem aspectos simbólicos desprezados pelo Sistema de Justiça Formal. Essas praticas tentam trazer à tona o que realmente foi vivenciado pelos envolvidos no conflito, reconhecendo os danos emocionais, materiais e morais ocasionados à vitima, à comunidade circunvizinha e ao próprio ofensor.

Tanto o Sistema de Justiça Formal quanto a Justiça Restaurativa entendem que o crime gera efeitos para as vitimas, para a comunidade e para o próprio agressor e que algo deve ser feito para suprir as necessidades dos envolvidos nos conflitos. A pretensão da Justiça Criminal de que os culpados pelo crime devem ser punidos, sob a égide da legalidade e proporcionalidade, se fundamentam no argumento de que a punição imposta pelo Estado é o único caminho apto para se fazer Justiça. Na Justiça Retributiva o Estado é a vítima, e a relação entre vitima e transgressor é irrelevante (ZEHR, 2008). A Justiça Restaurativa quebra esse paradigma ao questionar o fato de que somente a pena é eficaz para suprir a necessidade de justiça da sociedade. Os princípios da Justiça Restaurativa nos convidam a pensar diferente, apontam para o fato de que o processo formal apresenta falhas ao privar as vítimas, a comunidade e o ofensor da possibilidade de participação em uma solução que supra as necessidades dos afetados pelo crime. Na Justiça Restaurativa, as dimensões 
interpessoais são trazidas ao centro dos procedimentos, dando relevância para aos aspectos subjetivos dos envolvidos. Segundo Bandeira \& Batista (2007):

"A justiça restaurativa, ao propor esse outro paradigma, ora em desenvolvimento, tem como finalidade instalar-se cada vez mais, como uma alternativa sistemática, regular, completa e inclusiva, que veio para ficar, avançando em relação ao sistema penal punitivo e pretensamente reabilitatório. Se por um lado, a justiça penal tradicional, no Brasil, se baseia em uma cultura do conflito e da penalização, por outro, a experiência da Justiça Restaurativa vem se empenhando com o objetivo de desenvolver uma cultura de paz, mais centrada em uma prática conciliatória dos conflitos" (Bandeira; Batista, 2007: 6).

Dentro desse contexto, como síntese da investigação sociológica desenvolvida durante o trabalho de campo, percebeu-se que na visão dos operadores e auxiliares da Justiça, que atuam perante o Superior Tribunal de Justiça, alguns pontos são consensuais. Em primeiro lugar pode-se destacar a ineficiência do Sistema de Justiça formal em atender satisfatoriamente as demandas de cunho penal. Tal incapacidade é tributária da falta de estrutura material e humana do Judiciário, da Polícia e das Defensorias Publicas e da anacronia do código de processo penal que cria impedimentos à efetividade da Justiça.

Também foi percebida certa resistência dos entrevistados em relação às formas alternativas de resolução de conflitos. Analisando seus discursos percebese que tal resistência tem como algumas de suas prováveis causas a falta de conhecimento sobre a temática e a idéia de que o Estado é a única entidade capaz e legítima para a resolução dos conflitos sociais. Os envolvidos no conflito não são percebidos como entes aptos para terem o poder de solução de seus próprios conflitos o que gera a impressão de que não há legitimidade nas soluções restaurativas, mas só nas retributivas impostas exclusivamente pelo Estado. Esse discurso demonstra que, em certa medida, o sistema penal impede que os envolvidos apoderem-se de seus próprios conflitos, conforme discorre Nils Christie (1998:14):

"De acordo com o modelo penal tradicional, o Estado, através dos personagens que fazem parte das agências formais de controle social (Juízes, promotores, delegados, advogados, etc.), subtrai os conflitos das partes, transformam-nos em casos e as impede de participar diretamente da sua solução" 
A questão da pena como única medida capaz de satisfazer os anseios da sociedade também foi levantada. Na visão da maioria dos entrevistados as soluções restaurativas são percebidas pela sociedade como sinônimo de impunidade e é necessária uma fase claramente retributiva para que as pessoas percebam que foi feita a Justiça. Esses discursos também refletem certo conservadorismo e a superficialidade do conhecimento dos entrevistados visto que a Justiça Restaurativa, como procedimento complementar ao sistema formal, tem a capacidade de recompor a ordem jurídica ao encarar o crime com uma outra metodologia que gera melhores resultados para a vitima, que recupera a autoestima, a segurança, o controle da situação e a sua dignidade, além de provocar ao infrator a sua responsabilização pelo mal causado e the dar a oportunidade de reparar o erro (PINTO, 2005).

Apesar das barreiras descritas, notou-se que, de acordo com os entrevistados, há espaço no âmbito jurídico para a implantação de novas tecnologias de resolução de conflitos. Mesmo demonstrando receios e inseguranças, conforme exposto, os operadores e auxiliares da justiça parecem acreditar na aplicabilidade da Justiça Restaurativa para a resolução de determinados conflitos. Creio que a Justiça Restaurativa é um tema ainda distante da realidade pratica do mundo jurídico Brasileiro, principalmente no âmbito do Superior Tribunal de Justiça, mas parece que a aplicação dessas praticas tende a crescer e se tornar uma alternativa eficaz na resolução de conflitos e, consequentemente, uma ferramenta na disseminação do acesso à Justiça, conforme salienta Pinto (2008:201):

"É razoável concluir que o impacto da justiça restaurativa no contexto da comunidade jurídica brasileira e em nosso sistema de justiça criminal é ainda difícil de se avaliar, ou mesmo prever, porque não há ainda registro de divergências muito significativas no debate que existe a respeito, que é ainda incipiente. É possível que aflorem incredulidades, ceticismos, divergências, críticas, resistências e dificuldades que requererão estratégias adequadas de sensibilização." 


\section{BIBLIOGRAFIA}

ADORNO, S. “Direito e democracia. Diálogos \& Debates”, São Paulo, v. 1, p. 30-37, 2000;

ANDRIGHI, Fátima Nancy. "Formas Alternativas de Resolução de Conflitos". Artigo Publicado na página da biblioteca do Superior Tribunal de Justiça, disponível em http://bdjur.stj.jus.br/jspui/bitstream/2011/587/4/Formas Alternativas_Solu\%c3\%a7\%c3\%a3o.pdf; BAUMAN, Z. “O Mal-Estar da Pós-Modernidade”. Rio de Janeiro: Jorge Zahar Editor, 1998;

BATISTA, N. Novas tendências do Direito Penal. Palestra proferida no Centro de Estudos Judiciários, em 8 de maio. Disponível em: http://conline1.cjf.jus.br/phpdoc/pages/sen/portaldaeducacao/textos fotos/dpenal2003/NiloBatista. doc.,2003;

BIRBAUM, Pierre. "Conflitos", in Tratado de Sociologia. Rio de Janeiro: Jorge Zahar Editor, 1995;

BOUDON, Raymond. (org). "Desvio", in Tratado de Sociologia. Rio de Janeiro: Jorge Zahar Editor, 1995;

BRANDÃO, Delano Câncio. "Justiça Restaurativa no Brasil: Conceito, críticas e vantagens de um modelo alternativo de resolução de conflitos”. In: Âmbito Jurídico, Rio Grande, 77, 01/06/2010 [Internet];

BRAITHWAITE, J., "Restorative Justice," in M. Tonry, ed., Handbook of Crime and Punishment (New York: Oxford University Press): pp. 323-344, 1998.

"Values and Restorative Justice in Schools," in Restorative Justice:

Philosophy in Practice, H. Strang e J. Braithwaite eds., (Burlington, USA: Ashgate). PDF acessível no endereço http://www.crj.anu.edu.au/school.pubs.html, 2002;

CALDEIRA, Teresa "City of Walls: Crime, Segregation, and Citizenship in São Paulo" (Berkeley: University of California Press), 2000;

CAPPELlETTI, Mauro; GARTH, Bryart. “Acesso à Justiça” Porto Alegre: Ed. Sérgio Antonio Fabris, 1988;

"Processo, Ideologias e Sociedade.” Tradução Prof. Dr. Elício de Cresci Sobrinho. Porto Alegre: Sergio Antonio Fabris Editor, 2008;

CARVALHO, Luiza Maria S. dos Santos. "Notas sobre a promoção da eqüidade no acesso e intervenção da Justiça Brasileira" in Justiça Restaurativa. Brasília, Ministério da Justiça e Programa das Nações Unidas para o Desenvolvimento - PNUD, 2005;

CORNIER, B., La justice réparatrice : orientations et principes - évolution au Canada (Ministère du Solliciteur général du Canada, Sécurité publique et Protection civile, Travaux publics et Services gouvernementaux Canada) 2002; 
COSER, Lewis, "The function of social conflict". Glencoe, Ill.: Free P ress, 1956;

COSTA, Arthur.Violências e Conflitos Intersubjetivos no Brasil Contemporâneo, 2011 In Cadernos CRH, vol. 24 (62), 2011;

COSTA, Arthur; BANDEIRA. Lourdes (Orgs.). "A Segurança Pública no Distrito Federal: práticas institucionais e dilemas culturais.” Brasília: LGE Editora, 2007;

CHRISTIE, Nils. "Conversa com um Abolicionista Minimalista." In: Revista Brasileira de Ciências Criminais. Ano 6, n 21, janeiro-março, 1998, Revista dos Tribunais;

DAHRENDORF, Ralf. “A lei e a ordem.” Rio de Janeiro: Instituto Liberal, 1997; . "Class and Class Conflict in Industrial Society" Routledge \& Kegan Paul, London, 1988;

DUFF, A., "Restoration and Retribution," in A. von Hirsh, J. Roberts,A.E. Bottoms, K. Roach et M. Schiff, eds., Restorative Justice \& Criminal Justice. Competing or Reconcilable Paradigms? (Oxford and Portland: Hart Publishing): pp. 43-59, 2003;

EGLASH, A., "Beyond Restitution : Creative Restitution," in Galaway, B. e J. Hudson, eds., Restitution in Criminal Justice (Lexington, MA : DC Health and Company), 1977;

ELIAS, N. "O processo civilizador: uma história dos constumes." Rio de Janeiro: Jorge Zahar, 1990. vol. 2, parte II

FERREIRA, Jonatas, Org. "Da vida ao tempo: Simmel e a construção da subjetividade no mundo moderno."( Revista brasileira de Ciências Sociais v.15 n.44 São Paulo out. 2000 - Versão online). FREIRE, MOEMA DUTRA, "Acesso à Justiça e Prevenção à Violência." Dissertação de Mestrado apresentada ao Instituto de Ciência Política da Universidade de Brasília. 2006;

FOUCAULT, Michel. "Vigiar e Punir”. Petrópolis: Vozes, 2002;

HOLSTON, James, e CALDEIRA, Teresa "Democracy, Law, and Violence: Disjunctions of Brazilian Democracy," in F. Aguero e J. Stark, eds., FaultLines of Democracy in Post-Transition Latin America (Miami: North-South Center Press, University of Miami) 1998, pp. 263-296.

JACCOUD, Mylène. "Princípios, tendências e procedimentos que cercam a Justiça Restaurativa" in Justiça Restaurativa. Brasília, Ministério da Justiça e Programa das Nações Unidas para o Desenvolvimento - PNUD, 2005;

JUSTIÇA EM NÚMEROS 2010. Documento disponível em http://www.cnj.jus.br/images/programas/justica-emnumeros/2010/rel_justica_numeros_2010.pdf

KANT DE LIMA, Roberto (Org.) ; AMORIM, Maria Stella de (Org.) ; MENDES, Regina Lúcia Teixeira (Org.) . "Ensaios sobre a Igualdade Jurídica. Acesso à Justiça Criminal e Direitos de Cidadania no Brasil." Rio de Janeiro: Editora Lumen Juris, 2005;

LAHUERTA, M. \& AGGIO, A., "Pensar o século XX : problemas políticos e história nacional na América Latina." São Paulo : Universidade Estadual Paulista, 2003;

MIRANDA, Andrea Tourinho P. de "Justiça Restaurativa e a Reforma do Judiciário, Reflexões sobre a Importância da sua Institucionalização e Legalização”in Revista Persona, 2010; 
NAÇÕES UNIDAS, ECOSOC, "Development and implementation of mediation and restorative justice measures in criminal justice". (Res. 1999/26. Adotada em 28 Julho de 1999);

NAÇÕES UNIDAS, ECOSOC. "Basic principles on the use of restorative justice programs in criminal matters." (Res. 2000/14, Adotada em 27 de julho de 2000);

NUCCI, Guilherme de Souza. "Manual de Processo Penal e Execução Penal.” 4a. ed. São Paulo: Revista dos Tribunais, 2007;

OLIVEIRA, Luis Roberto Cardoso de. "Direito Legal e Insulto Moral: Dilemas de cidadania no Brasil, Quebec e EUA.” Rio de Janeiro: Elume Dumará, 2002;

O’DONNEL, Guillermo. "Poliarquias e a (In)Efetividade da Lei na América Latina.” Novos Estudos CEBRAP n. ${ }^{\circ}$ 51, Julho de 1998 pp37 - 62;

OXHORN, Philip e Slakmon, Catherine "Micro-justiça, Desigualdade e Cidadania Democrática. A Construção da Sociedade Civil através da Justiça Restaurativa no Brasil" in Justiça Restaurativa. Brasília, Ministério da Justiça e Programa das Nações Unidas para o Desenvolvimento - PNUD, 2005;

PESTANA, Débora. "Justiça penal autoritária e consolidação do estado punitivo no Brasil” in Rev. Sociol. Polit. vol.17 no.32 Curitiba fev. 2009;

PINHEIRO, P. S., "Violência e crime nas novas democracias : desafios para a próxima década." Disponível em http://www.iesambi.org.br/sociologia/desafio violencia.htm, 1997;

PINTO, Renato Campos De Vitto. "Princípios, tendências e procedimentos que cercam a Justiça Restaurativa" in Justiça Restaurativa. Brasília, Ministério da Justiça e Programa das Nações Unidas para o Desenvolvimento - PNUD, 2005;

PINTO, Renato Sócrates Gomes, "Os Operadores Jurídicos e a Justiça Restaurativa" Artigo originalmente publicado na Revista IOB de Direito Penal e Processo Penal, Porto Alegre, vol. 8, n. 47, dez. 2007/jan. 2008, pp. 190- 202;

SCHUCH, Patrice, "Tecnologias da não violência e modernização da justiça no Brasil". Revista Civitas, Vol. 8, № 3, Porto Alegre, 2008.

SCURO NETO, Pedro. "Manual de Sociologia Geral e Jurídica", São Paulo, Ed. Saraiva.2000. 3a ed.;

, "Por uma Justiça Restaurativa 'real e possível" Versão revista e ampliada da contribuição ao seminário internacional 'Justiça Restaurativa. Um Caminho para os Direitos Humanos?' Instituto de Acesso à Justiça (Brasil)/ Justice (Inglaterra). Porto Alegre, 29-30 outubro 2004

SIMEL, George. "Soziologie“, Leipzig: Duncker \& Humblot, 1908;

SIMMEL, George. "O problema da Sociologia". In : MOARES, F. E. de (org.). Simmel. São Paulo: Ática, 1983;

SIMMEL, G. "A Natureza Sociológica do Conflito" in, Evaristo de Moares Filho(org), Simmel. São Paulo: Ática, 1983; 
SPAGNA, Laiza. "A Viabilidade da Justiça Restaurativa no Distrito Federal.” Monografia, 2008 ;

STRAUSS, Anselm L. "Espelhos e Máscaras: A Busca da Identidade". São Paulo: Editora Universidade de São Paulo, 1999;

SUAREZ, Mireya \& BANDEIRA, Lourdes. "A politização da violência contra a mulher e o fortalecimento da cidadania." In: Gênero, Democracia e Sociedade Brasileira.

T.H. Marshall. "Cidadania, Classe Social e Status.” Rio de Janeiro: Zahar, 1967;

Van Ness, D. e K. H. Strong, "Restoring Justice" (Cincinnati, Ohio: Anderson Publishing Co). 1997;

WACQUANT, Löic “Prisões da miséria". Rio de Janeiro: Zahar, 2001;

WALGRAVE, L., 1993. Au-delà de la rétribution et de la réhabilitation : la réparation comme paradigme dominant dans l'intervention judiciaire contre la délinquance des jeunes ? in J. F. Gazeau e V. Peyre, eds., La justice réparatrice et les jeunes (Vaucresson, 9ièmes journée internationales de criminologie juvenile): pp. 5-28;

La justice Restaurative: à la recherche d'une théorie et $\mathrm{d}^{\prime}$ un programme. Revista Criminologie, Vol.32, No. 1, Canadá, 1999;

WIEVIORKA, Michel. "Violência Hoje". In: Ciência \& Saúde Coletiva, 11(Sup.): 1147-1153, 2007; "O novo paradigma da violência". In: Tempo Social São Paulo: Edusp. Vol.

9 (1): 5-41;

WOLKMER, Antonio Carlos, "Pluralismo jurídico. Fundamentos de uma nova cultura no Direito". São Paulo: Alfaômega, 2004;

ZEHR, H. J. "Changing lenses : a new focus for crime and justice" (Scott Dale, P.A., and Waterloo, Ont.: Herald Press): pp. 5-28, ., 1990.

"Trocando as Lentes: um novo foco sobre o crime e a justiça." Tradução de Tônia Van Acker. São Paulo: Palas Athena, 2008. 


\section{ANEXOS}

\section{1 - Lista dos Entrevistados}

1. Ministro Sebastião Reis Junior

2. Ministra Laurita Hilário Vaz

3. Ministro Vasco Della Giustina

4. Marlon Barreto - Assessor do Ministro Adilson Vieira Macabu

5. Edson Durães de Vellasco - Assessor do Ministro Cezar Asfor Rocha

6. Christiano Vasconcellos Salum Vieira - Assessor do Ministro Felix Fisher

7. Fernando Safe de Matos Coutinho - Assessor do Ministro Felix Fisher

8. Marcos Aurélio Pereira Brayner - Assessor da Ministra Laurita Vaz

9. Marcos José Tavares de Oliveira - Assessor da Ministra Maria Thereza de Assis Moura

\section{Roteiro das Entrevistas}

1. Em sua opinião, quais as dificuldades o Sistema Judiciário encontra para atender as demandas relativas às causas penais?

2. Você tem conhecimento de alguma forma alternativa de resolução de conflitos?

Se sim, qual a sua opinião sobre? Se não, dar exemplos e citar os projetos de justiça restaurativa, justiça comunitária...

3. Qual a sua opinião sobre a Justiça Restaurativa?

Qual a sua aplicabilidade no atendimento das demandas relativas às causas penais?

4. Você acredita que os sistemas são excludentes ou complementares?

Se eles são complementares, quais os limites de atuação de um e de outro sistema? Se eles são excludentes, em que pontos se chocam? (se há conflito entre os dois modelos. O que está em disputa?)

5. Em sua opinião, quais as possibilidades de atuação da Justiça Restaurativa?

Quais os impedimentos e dificuldades para a Justiça Restaurativa? Em que medida esses impedimentos são frutos da postura do Poder Judiciário e em que medida são frutos da própria Justiça Restaurativa? 